\title{
(8) IEB
}

Institut

d'Economia

de Barcelona

\section{Document de treball de l'IEB 2015/39}

'HOLD THAT GHOST': USING NOTCHES TO IDENTIFY MANIPULATION OF POPULATION-BASED GRANTS

Dirk Foremny, Jordi Jofre-Monseny, Albert Solé-Ollé 


\section{'HOLD THAT GHOST': USING NOTCHES TO IDENTIFY MANIPULATION OF POPULATION-BASED GRANTS}

Dirk Foremny, Jordi Jofre-Monseny, Albert Solé-Ollé

The IEB research program in Fiscal Federalism aims at promoting research in the public finance issues that arise in decentralized countries. Special emphasis is put on applied research and on work that tries to shed light on policy-design issues. Research that is particularly policy-relevant from a Spanish perspective is given special consideration. Disseminating research findings to a broader audience is also an aim of the program. The program enjoys the support from the IEB-Foundation and the IEBUB Chair in Fiscal Federalism funded by Fundación ICO, Instituto de Estudios Fiscales and Institut d'Estudis Autonòmics.

The Barcelona Institute of Economics (IEB) is a research centre at the University of Barcelona (UB) which specializes in the field of applied economics. The IEB is a foundation funded by the following institutions: Applus, Abertis, Ajuntament de Barcelona, Diputació de Barcelona, Gas Natural, La Caixa and Universitat de Barcelona.

Postal Address:

Institut d'Economia de Barcelona

Facultat d'Economia i Empresa

Universitat de Barcelona

C/ John M. Keynes, 1-11

(08034) Barcelona, Spain

Tel.: + 34934034646

ieb@ub.edu

http://www.ieb.ub.edu

The IEB working papers represent ongoing research that is circulated to encourage discussion and has not undergone a peer review process. Any opinions expressed here are those of the author(s) and not those of IEB. 


\title{
'HOLD THAT GHOST': USING NOTCHES TO IDENTIFY MANIPULATION OF POPULATION-BASED GRANTS *
}

\author{
Dirk Foremny, Jordi Jofre-Monseny, Albert Solé-Ollé
}

\begin{abstract}
We study local government incentives to misreport the information required to implement a formula grant. We focus specifically on population, in theory the easiest variable for the grantor to verify. We analyze the Spanish case and show how a switch from the use of census to registered population data (the latter administered by the municipalities) led to a manipulation of the population numbers used by central government to allocate grants to municipalities. As a result, registers included a proportion of 'ghost' citizens, that is, people who presented no trace of actually residing in the municipality. We identify the effects of grants on population over-reporting taking profit of notches in the grant scheme (i.e., one based on weighted population with the weights increasing at specific population thresholds). We document an excess mass of municipalities to the right of the notch threshold and a density hole to the left of it. There are several indications that manipulation (rather than real population responses) is the mechanism at work.
\end{abstract}

JEL Codes: H7, H26, D7

Keywords: Intergovernmental transfers, notches, bunching, enforcement

Dirk Foremny

University of Barcelona \&

IEB

Av. Diagonal, 690

08034 Barcelona, Spain

E-mail: foremny@ub.edu
Jordi Jofre-Monseny

University of Barcelona \&

IEB

Av. Diagonal, 690

08034 Barcelona, Spain

E-mail: jordi.jofre@ub.edu

\author{
Albert Solé-Ollé \\ University of Barcelona \& \\ IEB \\ Av. Diagonal, 690 \\ 08034 Barcelona, Spain \\ E-mail: asole@ub.edu
}

\footnotetext{
* We gratefully acknowledge helpful comments received from Roland Hodler and Ami Glazer, participants at the UEAMeeting (WashingtonDC), the European Public ChoiceMeeting (Groningen), the 2015 CESifo Public Economics Conference, the 2015 ZEWPublic Finance Conference, the 2015 meetings of the European Economic Association (Mannheim), the 9th Meeting of the Urban Economics Association (Washington), the IIPF 2015 (Dublin), and at seminars at UCI-Irvine and DIW Berlin. This research has received funding from projects ECO201237131 and ECO2013-41310 (Ministerio de Economía y Competitividad) and 2014SGR-420 (Generalitat de Catalunya).
} 


\section{Introduction}

Local governments across the globe receive a substantial share of their revenues in the form of grants from higher-level governments. In 2010, for example, this share was as high as $70 \%$ in the United Kingdom and the Netherlands. In other countries the share is smaller and local governments have more autonomy over their own resources (Foremny, 2014). In Spain, nearly $40 \%$ of all local revenues are allocated as grants, high enough to warrant special attention.

The way in which these grants are allocated to cities and municipalities differs across countries. The optimal allocation of grants has been discussed extensively (see Oates, 1972, 1999; Wildasin, 1986; Bird and Smart, 2002, for surveys) and it is typically concluded that they should be allocated as unconditional block grants, so that local spending and taxation decisions are not distorted. At the same time, it is argued that grants should be formula-based to avoid any political bias in their allocation (Dixit and Londregan, 1995; Persson and Tabellini, 2002). Most formula grants, however, are vulnerable to manipulation by recipients because information concerning the criteria applied is distributed asymmetrically between levels of government (Bordignon, Manasse, and Tabellini, 2001; Huber and Runkel, 2006). Although the academic literature has not paid much attention to this issue, the difficulties in gathering reliable data to implement these formulas are a concern for both policy makers and advisers (see, e.g., Boex and Martínez-Vázquez, 2007 and Bahl, 2000). For instance, grantors, whose equalization formulas rely on measures of tax capacity, need to be able to secure this information, since, if tax collection is in the hands of local governments, there might be incentives to under-report the tax base to the higher tiers of authority. Countries that use complex calculations of spending needs are also particularly vulnerable to incentives to withhold information (e.g., Australia, the UK, and the Nordic countries, see Kim and Lotz, 2008). Ultimately, the failure to address these problems can undermine the workings of such grants. According to Bahl (2000):

"A major constraint to designing a formula grants system is finding the data to implement and update the system. An important underlying issue is this: formula grants are appealing because their transparency and objectivity. These advantages can be taken away if the data to allocate the funds are suspect." (p.14)

It has often been argued that the least distortionary and manipulable way of allocating grants are schemes based on the number of inhabitants. However, if the collaboration of local governments is required for the collection of population information, even this variable might potentially be manipulated. Such a problem may be especially acute in developing countries, where the central government lacks the capacity to monitor population in the field effectively (see again Boex and Martínez-Vázquez, 2007). Therefore, governments seeking to implement a system in which the allocation of grants is based on population face a trade-off between accuracy and manipulability. Increasing accuracy by relying on local government reports (as opposed to using, for example, expensive and outdated decennial census data) might create incentives to 
manipulate population figures, unless the central government can dedicate sufficient efforts to ensure compliance.

In Spain, our case of study, municipalities are responsible for the administration of their population registers (Padrón Municipal de Habitantes), which are also subject to constant coordination and monitoring by the Spanish Statistics Office (INE), a central government agency. Since 1998, grants from the central government to the municipalities have been allocated using these population registers. For several years, central government monitoring was far from perfect and the registered population was systematically inflated. Indeed, the population censuses carried out in 2001 and 2011 uncovered huge numbers of 'ghost' residents, i.e., individuals for whom there was no actual evidence of their residing in the respective municipality. Moreover, several scandals have been reported in which city councils have been accused of systematically manipulating population numbers. The most notorious of these took place in Santa Cruz de Tenerife (the main city in the Canary Islands). In an audit released in 2009, the INE found nearly 15,000 'ghost' residents (around 7\% of the population), with evidence of fraudulent use of ID documents, among other irregularities. Immediately following the publication of the audit, the mayor of Las Palmas (the second city in the Canary Islands) complained about the loss of grants suffered by his city due to the over-reporting of population in Santa Cruz and, more generally, about the harm done to the objectivity of the allocation of grants to municipalities in the region. ${ }^{1}$

Theoretically, for a given level of enforcement, over-reporting will be larger the more generous these grants are (i.e., the higher the amount of money linked to an additional resident). To the best of our knowledge, no previous attempt has been made to estimate the effect of grant generosity on population over-reporting in order to approximate the magnitude of the problem in real settings. The reason for this is probably that it is very difficult to estimate this magnitude for a linear grant scheme. Fortunately for our purposes, in Spain, per capita grants to municipalities jump at given population thresholds. Specifically, the grant per inhabitant changes discontinuously at thresholds of 5,000, 20,000 and 50,000 inhabitants for the entire local population. If grants per capita increase discontinuously at population thresholds, incentives for municipalities to sort to the right of the threshold are very strong, as one additional inhabitant brings additional grants for all existing inhabitants. Thus, municipalities face strong incentives to misreport population figures. In fact, there is considerable anecdotal evidence from the municipalities citing the increase in grants to justify an aggressive policy of seeking to boost their populations above one of these thresholds.

Policies that create jumps in governments' choice sets are commonly referred to as notches (Slemrod, 2010). We make use of these notches to estimate the effect of grant generosity on

\footnotetext{
${ }^{1}$ The undue amounts received by Santa Cruz, during a ten-year period, were estimated at around 40 million euros, while the mayor estimated the amount of grants lost by Las Palmas at around 6.5 million euros (see "The mayor of Las Palmas demands compensation for municipalities because of the fraud in the Santa Cruz register", in www.eldiario.es, 07/02/2014).
} 
population over-reporting. This paper is, to the best of our knowledge, the first to exploit notches in intergovernmental grants to study the responses of local governments. Specifically, we use the methods developed in the taxation literature (Saez, 2010; Chetty et al., 2011; Kleven and Waseem, 2013) to quantify bunching that, in our case, corresponds to the excess density found above the notch points ${ }^{2}$. We also estimate the implied responses of population overreporting to grant generosity. We perform several heterogeneity analyses (by period and type of municipality) that, linked to a stylized theoretical model of population reporting, help us to interpret our results.

We find significant responses and a huge amount of heterogeneity in the responsiveness of municipalities to grants. To the left of the 5,000 threshold, there is a loss of mass of around $10 \%$ of the municipalities. In the most extreme cases, over-reporting can be as high as 1,000 additional residents, although on average it is around 60 residents. This implies that, for the most responsive municipalities, the elasticity of population over-reporting to grants is about 0.40 , while the average response is around 0.013 . The extrapolation of this last number to the whole distribution of municipalities indicates that the leakage of grant money due to population over-reporting could be in the order of 40 million euros per year, suggesting potential gains from improvements in audit policies. In fact, we find that the extent of over-reporting is higher during the period 1998-2005, and almost disappears after 2005, coinciding with an improvement in the enforcement of population numbers by the INE. We also show how the census is able to identify the non-compliers, that is, the municipalities that were moved down below the 5,000 threshold due to discrepancies between the register and the 2001 census. Non-compliers tend to have high shares of foreign population and second homes and a low level of civic capital (as measured by turnout) and of electoral competition (as measured by the incumbent's margin of victory). These results are consistent with our model's predictions and help explain the heterogeneity we found in the responses. Several pieces of evidence suggest that manipulation (as opposed to real population responses) is the mechanism generating the observed bunching patterns. A number of robustness checks indicate that these bunching patterns are not likely to be explained by other institutional arrangements that also change discontinuously at population thresholds.

Local policies that depend discontinuously on municipality size provide an opportunity to use the regression discontinuity design to estimate the effects of these policies on fiscal and political outcomes. In a detailed study of the French, German and Italian cases, Eggers et al. (2015) identify the threats to identification that arise in this setting and provide guidance for addressing them. As in our study, these authors document discontinuous densities around the relevant population thresholds in all three countries. Hence, the manipulation of population figures by local authorities seems to be a widespread phenomenon in Europe. Our study differs from Eggers et al. (2015) in the following respect: While their study is concerned with the

\footnotetext{
${ }^{2}$ For an updated review of papers studying bunching see Kleven (2016)
} 
consequences of sorting when estimating the effects of policies that change discontinuously at population thresholds, we use the sorting induced by the policy discontinuity to quantify the effect of grants on population over-reporting.

The paper that is closest to ours is Litschig (2012), which shows that grants allocated through a population-based formula in Brazil are not effectively shielded from special-interest politics. The central government, responsible for the administration of relevant population information, inflated the population numbers of its politically aligned municipalities. As a consequence, aligned municipalities received on average more grants than those received by nonaligned municipalities. This is a clear indication that higher-level governments may implement formulas that they can subsequently manipulate in their favor. The findings in Litschig (2012) and our own outcomes are similar, in the sense that both point to the difficulty of avoiding the manipulation of simple population-based formula grants. The mechanisms that account for the results are, however, different: in Litschig (2012), it is the national government that manipulates population numbers, while in our case, it is the local governments that manipulate the transfer scheme due to the imperfections in the auditing policies of the national government.

The paper is also related to the tax enforcement literature, see e.g. Slemrod (2007) and Besley and Persson (2013). Our results on the responses to grant generosity mirror those of papers providing evidence on the effect of tax rates on tax evasion (Fisman and Wei, 2004). Our findings on the effect of improved monitoring add to the evidence provided by many studies on the effects of third-party reporting, crosschecking and other tax enforcement technologies (Bird and Zolt, 2008; Kleven et al., 2011). The evidence that the non-compliers are municipalities with low civic capital and electoral competition is in line with other papers that show that tax compliance is influenced by social capital and political incentives (Casaburi and Troiano, 2015; Besley, Jensen, and Persson, 2015). Note also that, as in our case, these last two papers deal with non-compliance that materializes in missing houses and population. ${ }^{3}$

The rest of the paper is organized as follows. In Section 2 we describe the institutional background in detail. In Section 3, we develop a stylized model of population over-reporting to guide the empirical findings. The empirical methods and data are described in Section 4 while the results are presented and discussed in Section 5. Section 6 concludes.

\footnotetext{
${ }^{3}$ The paper by Casaburi and Troiano (2015) analyzes the effect of an Italian enforcement program that used aerial photographs to uncover a massive number 'ghost buildings' (i.e., property not included in the land registry and thus hidden to the tax authorities) that boosted local property tax revenues. In the second paper, Besley, Jensen, and Persson (2015) focus on the evasion of 'poll tax' liabilities in UK. After the introduction of the poll tax, more than four million of voters disappeared from the electoral register and some local authorities and academics believed that these missing voters were trying to evade the poll tax (see "'Missing' 3.4 million voters put MPs at risk: poll tax evasion could distort review”, The Independent 17/06/1993). Scottish local authorities are still searching their half million missing voters (see "Councils plan to track down poll tax dodgers among 'missing' million voters", The Express, 30/9/2014).
} 


\section{Institutional background}

\subsection{Local governments in Spain}

The size of the local government sector in Spain is moderate, with municipal budgets representing around 15 per cent of total public spending in our period of study. Spanish municipalities have spending responsibilities similar to those in other countries (e.g., water supply, refuse collection and treatment, street cleaning, lighting and paving, parks and recreation, traffic control and public transportation, social services, etc.), with the sole exception of education, which is the responsibility of regional governments. In terms of revenues, in 2012, inter-governmental grants represented 36 per cent of local operating budgets, and 68 per cent of these transfers were in the form of a formula-based block grant allocated by the central government (the Participación Municipal en los Ingresos del Estado - PIE). This grant - as all other financial concerns of Spanish local governments - is regulated by a law passed in 1988 by the central government (Law 39/1988 Reguladora de Haciendas Locales) and applies to all the municipalities in the country. Although the variables and their exact weights have experienced (minor) changes over time, (weighted) population determined the allocation of 75 per cent of its funds during the years of our study. ${ }^{4}$

[Figure 1 about here]

To account for supposedly differential spending needs, a weight of 1 is applied to residents in municipalities with fewer than 5,000 inhabitants. This weight then jumps to 1.17, 1.3 and 1.4 as the population of the municipalities surpasses the thresholds of 5,000, 20,000 and 50,000 inhabitants, respectively. ${ }^{5}$ As such, the weight or multiplier is not applied exclusively to the population in excess of the threshold, but rather to the entire population of the municipality. The effect of the weighting scheme on per capita resources depends on the size of the pot of funds to be distributed each year, which is determined by the evolution of national tax revenues. Panel a) of Figure 1 illustrates this with data from 2005 budgets. In that year, the amount of per capita resources was 96, 113, 125 and 135 euros for municipalities below 5,000, between 5,001 and 20,000, between 20,001 and 50,000, and above 50,000 inhabitants, respectively. The absolute amount of resources involved are 85,000, 240,000 and 500,000 euros per year, provid-

\footnotetext{
${ }^{4}$ The other variables used in the formula are fiscal effort, the inverse of tax capacity, and the number of school units. There is a consensus among scholars that these elements do not work properly, see Solé-Ollé and Bosch (2005). For instance, the fiscal capacity equalization element is very poorly designed and, as a consequence, it does not contribute significantly to reduce differences in tax revenues.

${ }^{5}$ Currently, the law establishes a different funding scheme for municipalities with more than 75,000 inhabitants, which obtain a share of tax revenue in specific taxes (income, VAT and excises). Before 2003, these municipalities were also funded by the PIE, and there were additional population thresholds fixed at 100 and 500 thousand inhabitants. The coefficients at these thresholds were quite high (1.5 and 2.85, respectively) and so the incentives would also have been great. However, the very small number of municipalities close to these thresholds means any analysis is not feasible.
} 
ing strong incentives to municipalities to ensure they find themselves on the right side of the threshold. This is shown in Panel b) of Figure 1 for the 5,000 threshold.

\subsection{Local population figures}

In Spain, the population census is carried out every tenth year (the last three corresponding to 1991, 2001 and 2011). In 1991, the census quantified the permanent population in each Spanish municipality by visiting all households in the country. A similar operation also took place in 1996 (known as the Renovación padronal) so as to reduce the excessive time lapse between censuses. At that time, the population levels resulting from these large-scale field projects, run by the Spanish Statistics Office (INE), were the only official local population figures available. The outcomes were also accepted as the municipal population registers (Padrón municipal) for 1991 and 1996, respectively. The local authorities updated this register yearly to account for births, deaths and migrations. The register provided a population count for non-census years that was used, for instance, to create electoral censuses. However, since population was used in the allocation of grants, the government was already concerned that municipalities might have incentives to inflate their registered population. As a result, grants were only distributed according to official population counts. Specifically, the 1991 census was used to distribute grants for the period 1991-1997 whereas grants in 1998 were distributed in accordance with the 1996 population count.

The INE was given responsibility for coordinating and monitoring the Padrón in 1996 and since 1998 there has been an official annual population count (with base date January 1st) that is used to allocate grants. The municipalities have to report changes to the Padrón on a monthly basis. The INE compares the Padrón of all the municipalities with its own administrative records and communicates the official population to each municipality. This, therefore, is the number of inhabitants reported by the municipality net of any adjustments made by the INE. In this way, the INE is able, for example, to avoid a Spanish national being registered in two different municipalities: when a person moves to another city and registers there, the INE automatically deletes that individual from the register of the city of origin. Similar automatic adjustments are made for births and deaths. The decision to base the allocation of grants on the number of registered population reflected the optimism in the workings of the INE's automatic computerized monitoring system. However, in practice, the monitoring by INE has been far from perfect for a number of years as it has had to face various challenges:

- Unreported migrations abroad. Irrespective of their legal status, immigrants have strong incentives to register. First, registration is a necessary condition to access the main public goods and services (including health care and education). Second, it can serve as proof of residence in case of (extraordinary) regularization processes, such as those that took place in 1996, 2000, 2001, and 2005. However, when immigrants return home (or 
move to another country) they do not communicate the fact that they have abandoned the country (and the municipality) of residence. This means that the number of immigrants is inflated in the register. Municipalities claim that it is very costly to identify the immigrants that have left the city, and that there is no deliberate attempt on their part to manipulate population figures. Note, however, that by law the updating of the population register is a municipal responsibility, so municipalities that do not attempt to clean the register are shirking on their responsibilities.

- Over-registration of visitors. This is the case of EU citizens and also of Spanish nationals that spend part of the year in the municipality (e.g., they own a second home). Clearly, if they spend most of the time in the municipality, they should be considered residents and the city council should have the right to claim additional transfers. However, municipalities tend to include them in the register without paying too much attention to the length of time they spend there. In fact, there is ample anecdotal evidence of municipalities dedicating considerable efforts and resources to campaigns designed to convince these people to register. ${ }^{6}$ In some of the most blatant cases of population over-reporting, municipalities registered people in the street as if they were simply conducting a survey. This behavior might not be illegal but it is clearly unethical, and should also be qualified as shirking, because by law municipalities should only include in the register full time residents.

- Incorrect inclusion in the register. Of course, this might be due to administrative error, which is the typical claim made by local councils. For example, a resident might be included in the register more than once (i.e., in different cities) under slightly different names and/or with different documents giving proof of identity (which happens mostly in the case of immigrants and EU citizens). However, in many cases the discrepancy is due to overt attempts to manipulate the register and as such the municipality is legally responsible. For example, the INE's internal investigation of the case of Santa Cruz de Tenerife revealed that "there were sheets and sheets of names in the register with thousands of false ID documents, while other names were duplicated one after another - entire blocks of neighbors that simply did not exist". The INE found “15,000 'ghost' residents after crosschecking the register with an ID database from the Ministry of the Interior, 5,000 were Spanish nationals without a proper ID document, 7,500 were Spanish nationals without any proper proof that they registered, and 2,500 foreigners that had left the city" ${ }^{7}$ The attorney general initiated an investigation that proved the existence of fraud

\footnotetext{
${ }^{6}$ For instance, in Cardona (a small town near Barcelona), the mayor sent a letter to all residents telling them: "We encourage all the inhabitants of Cardona to lend a hand in enlarging our municipal register (...) with the aim of avoiding the loss of resources"; the letter included detailed instructions on how to register (see "Cardona takes action to find more residents", in La Vanguardia 8/12/2014, www.lavanguardia.com).

${ }^{7}$ See "Suspicion of fraud in the register of Santa Cruz de Tenerife. Commission set up to investigate more than 15,000 false IDs", www.elconfidencialautonomico.es, 17/04/2013.
} 
and as a result both population numbers and grant amounts were adjusted downward. ${ }^{8}$

The government had known about the existence of some of these problems since the implementation of the system in 1998, but their magnitude was probably unexpected. Note, for instance, that the huge immigration boom experienced in Spain during those years would have been unexpected in 1998. During this period there was also a massive boom in housing construction along the coast that would have exacerbated the problems related to the monitoring of population in tourist areas. However, the INE has learned from these developments and during the period it has progressively improved enforcement through the implementation of several data cleansing and auditing operations:

- The 2001 census was the last field operation involving visits to all households. It produced a municipal population figure for November 2001. The census operations revealed large discrepancies with the register and municipalities were required to justify these discrepancies or to make the necessary downsize adjustments. These operations were extended until the end of 2004.

- To deal with the problems involved in monitoring immigrants, namely the underreporting of out-migration and double counts, in 2005 INE made it compulsory for nonEU immigrants to renew their registration every second year. In practice, all immigrants registered before December 2003 that failed to re-register were deleted from the register in December 2005. A similar mechanism has also been implemented for EU residents who, from March 2009, must also re-register every fifth year.

- To deal with problems of fraud involving Spanish nationals, in 2009 the INE started to cross-validate the register with the aforementioned ID database built by the Ministry of the Interior.

- The last census was conducted in 2011. It constituted a survey as opposed to a census, with only about $12 \%$ of the population being interviewed. One of its objectives was to increase the accuracy of the register and, indeed, the probability of being surveyed was very high among the groups suspected of being over-represented in the register. Municipalities have subsequently been required to make the necessary downsize adjustments.

Three conclusions emerge from this discussion. First, it has been easier for some councils to over-report than it has been for others. This is the case of municipalities with high numbers of immigrants (both non-EU and EU citizens) and those that are home to many second residences. Second, while some of the over-reporting can be attributed to statistical errors, there is plenty of anecdotal evidence suggesting there has been overt manipulation of population

\footnotetext{
${ }^{8}$ As a result of this investigation the INE created another irregularity item named "Spanish national older than 16 not included in the ID database". See "Whoever inflated the registers will have to pay for the fraud", www.laopinion.es, 06/ 04/2013.
} 
numbers. In some cases the manipulation is due to the municipalities shirking on their responsibilities on management of the register while in other cases involves committing illegal acts and so should be qualified as cheating or fraud. Although only fraud can be legally punished, both types of behavior are clearly unethical and might thus entail some punishment by voters. This suggests that we should find that, controlling for opportunities for over-reporting, places with less civic capital (i.e., were voters dislike more breaking the rules) and with politicians that are less subject to political control should over-report more. Third, the ability of the INE to monitor the municipal register seems to have improved over time (i.e., after 2005). If the excess mass observed to the right of the thresholds is explained by manipulation, this phenomenon should be less intense in the last years of our sample. Of course, analyzing bunching in the 1991, 2001 and 2011 censuses provides further evidence to disentangle manipulation from actual population growth as the underlying mechanism at work.

\section{A model of population over-reporting}

With the only purpose of guiding the interpretation of our empirical findings, we develop a highly stylized model for a local government that has to decide how much it should overstate the real population of the municipality when reporting to central government. The model is similar to a tax evasion model with endogenous probability of detection (Yitzhaki, 1987; Kleven et al., 2011), although adapted to the specific characteristics of the case in question. In this model, the local government must determine the degree to which it will over-report its population, taking into account the benefits it can gain from additional transfers and the potential costs from being caught inflating its statistics. The cost of over-reporting depends on the probability of being caught and on the subsequent consequences for the local incumbent.

The section is organized as follows. First, we show how the local government determines the amount of population it will over-report in the case of a linear transfer schedule (i.e., a transfer allocated proportionally to population). Second, we analyze how the amount of population over-reported is affected by the presence of a notch in the transfer schedule. Third, we make the model more realistic by introducing both heterogeneity of preferences and population shocks in simulations.

\section{Linear transfer schedule}

For the moment, we assume that the amount of transfers $\tau$ received by a local government is the product of the level of reported population $r$ and per capita transfers $\alpha$ (i.e., $\tau=\alpha r$ ). Let's define $e=r-n$ as the level of over-reported population, where $n$ is the number of residents in the municipality (which we assume to be exogenous) and $r$ is reported population. The probability that population over-reporting is detected is denoted by $p(e)$. We parametrize $p$ 
using the following Pareto distribution $p=1-e^{\gamma}$ where $-1<\gamma<0$.

The local government maximizes the following expected utility function:

$$
u=(1-p) \alpha(n+e)+p(\alpha n-\theta e)
$$

which can be re-written as:

$$
u=\alpha n+\alpha e-p(\alpha+\theta) e
$$

where $\theta$ measures the cost per over-reported citizen if caught. This specification means that costs are higher for greater as opposed to smaller deviations, given that massive over-reporting can hardly be attributed to error. Among these costs accounted for by $\theta$, we can cite: (i) the harm caused to the reputation of the local incumbent, since detection might reveal the incumbent to be untrustworthy; (ii) a reduction in the incumbent's electoral prospects, due to a downgrade in the quality of local services and/or an inability to fulfill promises to improve services with the expected additional transfers; and (iii) in the most extreme cases (i.e., when the courts can prove deception), penalties might be imposed on those involved (including, for example, disqualification from public office, fines, and even imprisonment). ${ }^{9}$

The first order condition that maximizes (2) is:

$$
e^{*}=\left(\frac{\theta}{\alpha+\theta} \frac{1}{\gamma+1}\right)^{1 / \gamma}
$$

Given that $-1<\gamma<0$, it can readily be seen that over-reporting increases with per capita grants $(\alpha)$, decreases with the costs faced if caught $(\theta)$ and increases if the probability of being caught is low ( $\gamma$ is small in absolute value).

\section{Notched transfer schedule}

Let's now consider the outcomes when the transfer schedule has a notch. The notched schedule can be written as:

$$
\tau=[\alpha+\beta d(r>\hat{r})] r
$$

Where $d(r>\hat{r})$ is a dummy variable equal to one if the reported population is larger than the threshold $\hat{r}$. According to this expression, per capita transfers are equal to $\alpha$ if $r \leq \hat{r}$ and equal to $\alpha+\beta$ if $r>\hat{r}$. At the notch threshold, increasing the reported population by one inhabitant causes the transfers to jump by $\beta \hat{r}$, thus creating powerful incentives to over-report. The utility

\footnotetext{
${ }^{9}$ Note therefore that the model is agnostic with respect to the possible illegal nature of the act. Both shirking and cheating or fraud can thus be accommodated within this framework.
} 
of a municipality with a notched transfer is:

$$
u=(1-p)[\alpha+\beta d(r>\hat{r})](n+e)+p[(\alpha+\beta d(r>\hat{r})) n-\theta e]
$$

Figure 2 illustrates the expected utility level with a notched transfer scheme with a discontinuity at $\hat{r}$. The increase in utility at the notch is $(1-\hat{p}) \beta \hat{r}$. That is, the increase in grants, $\beta \hat{r}$, times the probability of not being detected, $1-\hat{p}$, where $\hat{e} \equiv \hat{r}-n$ and $\hat{p} \equiv p(\hat{e})$. In the example shown in Figure 2, the municipality is close enough to $\hat{r}$ and the expected utility at the threshold, $u(\hat{r})$, is higher than at its interior equilibrium, $u\left(r^{*}\right)$. As it delivers higher utility, this municipality will report $\hat{r}$.

[Figures 2 and 3 about here]

Panel a) in Figure 3 shows all three possible cases. The dotted line depicts the case of a municipality that is too far from the threshold. Here, $u\left(r^{*}\right)>u(\hat{r})$ and so the municipality will report its interior equilibrium level, $r^{*}$. The dashed line corresponds to the case illustrated in Figure 2 in which the municipality is better off reporting $\hat{r}$. Finally, the solid line defines the municipality that is indifferent between reporting $r^{*}$ and $\hat{r}$. For this marginal municipality, which we denote by $\tilde{r}$, the utility achieved at its interior optimum is equal to the utility at the notch, i.e., $u\left(r^{*}\right)=u(\hat{r})$, which implies:

$$
\alpha n+\alpha e^{*}-p^{*}(\alpha+\theta) e^{*}=\alpha n+\alpha \hat{e}-\hat{p}(\alpha+\theta) \hat{e}+(1-\hat{p}) \beta \hat{r}
$$

The utility that a municipality can achieve at notch $\hat{r}$ can be broken down into two parts, as shown in Figure 2. The first three terms on the right-hand side of equation (6) reflect the utility at $\hat{r}$ in the absence of the extra funds, while the last term captures the utility jump at the threshold, $(1-\hat{p}) \beta \hat{r}$. Note that the $\alpha n$ terms drop out of equation (6) which yields $\left(\alpha e^{*}-p^{*}(\alpha+\theta) e^{*}\right)=(\alpha \hat{e}-\hat{p}(\alpha+\theta) \hat{e})+((1-\hat{p}) \beta \hat{r})$. The left-hand side of this equation is a constant term, since $e^{*}$ and $p^{*}$ do not vary across municipalities. It turns out that the righthand side increases with population $(n)$. For $e>e^{*},(\alpha e-p(\alpha+\theta) e)$ diminishes with $e$. Hence, $(\alpha \hat{e}-\hat{p}(\alpha+\theta) \hat{e})$ increases with $n$ as $\hat{e}=\hat{r}-n$. The second term, $(1-\hat{p}) \beta \hat{r}$, also increases with $n$ because of the lower probability of being caught when reporting $\hat{r}$. Hence, there is a unique $\tilde{n}=\tilde{r}-e^{*}$ for which (6) holds. This has the effect of modifying the reported population density function as shown in Panel b) of Figure 3. All municipalities with $r^{*}$ between $\tilde{r}$ and $\hat{r}$ will report $\hat{r}$, creating an excess mass at exactly this point, which corresponds to the density hole between $\tilde{r}$ and $\hat{r}$.

The location of the 'marginal buncher' identifies the reported population change induced by the notch, $d r$, which amounts to $\hat{r}-\tilde{r}$. A measure of the change in grants faced by the marginal buncher enables us to identify the responsiveness of reported population to grants. When moving from $\tilde{r}$ to $\hat{r}$, grants increase by $\alpha(\hat{r}-\tilde{r})+\beta \hat{r}$. Relative to the increase in reported 
population, this grant increase is $\alpha+\beta \hat{r} /(\hat{r}-\tilde{r})$. Given that just below $\tilde{r}$ grants increase by $\alpha$, grants per reported inhabitant increase by $\beta \hat{r} /(\hat{r}-\tilde{r})$ between $\tilde{r}$ and $\hat{r}$. Hence, the elasticity of reported population to grants can be estimated as follows:

$$
\epsilon_{r, \alpha}=\frac{d r / r}{d \alpha / \alpha} \simeq \frac{\frac{\hat{r}-\tilde{r}}{\tilde{r}}}{\frac{\hat{r}}{\hat{r}-\tilde{r}} \frac{\beta}{\alpha}}=\frac{(\hat{r}-\tilde{r})^{2}}{\hat{r} \tilde{r}} \frac{\alpha}{\beta}
$$

\section{Heterogeneity and population shocks}

The stylized model outlined above can be made more realistic by relaxing some of its assumptions. First, we allow $\gamma_{i}$ to be heterogeneous to reflect the fact that some municipalities might have more possibilities of over-reporting than others. To analyze what 'bunching' might look like in this scenario, we resort to simulations. The results are presented in Panel b) of Figure 4. Compared with the baseline case with no heterogeneity - shown in Panel a) - we see that now the range that goes from $\tilde{r}$ to $\hat{r}$ is not completely empty. Indeed, approaching $\tilde{r}$ there are many municipalities for which deviating from the optimum is now too costly; the proportion of these municipalities decreases steadily as one approaches the notch threshold. Second, real population ( $n$ ) might be affected by shocks and these shocks would make it difficult to control the reported population. Panel c) shows the density function if we consider both heterogeneous $\gamma_{i}$ 's and exogenous shocks in population simultaneously. Bunching becomes fuzzy in this scenario (i.e., note that there is also a spike in the density immediately prior to the threshold), which is what we would expect to find in the empirical densities that we analyze below.

[Figure 4 about here]

\section{Bunching identification and data}

\subsection{Identifying bunching in practice}

To quantify bunching behavior, we follow Kleven and Waseem (2013) whose procedure is summarized in Figure 5. Specifically, bunching at a notch point can be quantified by calculating the difference between the empirical density and an estimated counterfactual density.

[Figure 5 about here]

Choosing $r_{L}$ and $r_{U}$ defines the excluded range (the area suspected to be affected by bunching behavior, where $L$ stands for the lower bound and $U$ for the upper bound). Grouping municipalities into population bins indexed by $j$, the counterfactual distribution is estimated by fitting a polynomial of order $q$ to the actual distribution of population bin counts $\left(c_{j}\right)$, where 
dummies are included for the bins in the excluded range:

$$
c_{j}=\sum_{h=0}^{q} \beta_{h}\left(r_{j}\right)^{h}+\sum_{i=r_{L}}^{r_{U}} \gamma_{i} \mathbf{1}\left[r_{j}=i\right]+\varepsilon_{j}
$$

The (estimated) counterfactual distribution is built with the polynomial coefficient estimates

obtained in (8), namely, $\widetilde{c_{j}}=\sum_{h=0}^{q} \widetilde{\beta_{h}}\left(r_{j}\right)^{h}$. The difference between the empirical and estimated densities provides us with a direct measure of $B$ (the excess mass between $\hat{r}$ and $r_{U}$ ) and of $M$ (the missing mass between $r_{L}$ and $\hat{r}$ ). In practice, it might not always be obvious how to choose the excluded range, that is, $r_{U}$ and $r_{L}$. The excess mass should be relatively concentrated to the right of the notch point and, following Kleven and Waseem (2013), we choose the upper limit $r_{U}$ by visual inspection. Then, we choose $r_{L}$ by equating the excess mass above the notch $(B)$ with the missing mass below the notch $(M)$. The method also requires the researcher to specify $q$, the polynomial order of the counterfactual density. The city size distribution has been widely studied in the urban economics literature, and while there is some controversy as to which parametric distributions best fit the data (see, for example, Gabaix, 1999 and Eeckhout, 2004), the city size distribution is smooth and can be well approximated by a low-order polynomial. In our baseline specification, we choose a second-order polynomial (i.e. $q=2$ ), although we test the robustness of the results to higher-order polynomial specifications. To assess the statistical significance of the results, we follow Chetty et al. (2011) and compute standard errors using the residual bootstrap.

\subsection{Data}

We use official population data as recorded in the municipal registers (the Padrón municipal) for the years 1998-2011. The data are for 1 January and they are the same figures as those used to determine the allocation of the PIE. Note that this concept does not correspond exactly with that of 'reported population' as used in the theoretical section, since we are unable to measure 'reported population'. Clearly, this information is at the disposal of the INE, since it corresponds to the population numbers remitted by the municipalities, but the statistics office does not disclose these figures to preserve the confidentiality of the monitoring procedures employed. Our official population numbers are reported as population $+/$ - any adjustments that the INE successfully imposed on the municipalities in the months immediately following reporting. Thus, in practice, we are seeing distortions in the distribution of corrected population; in terms of the theoretical model, this would amount to $r-p(e) e$. Note, however, that the qualitative prediction on this variable is exactly the same as that for $r$, unless instantaneous monitoring is completely effective. Clearly, following an increase in enforcement, the amount of bunching of both official and reported populations decreases.

As explained in Section 2, per capita grants change at thresholds of 5,000 20,000 and 50,000 
inhabitants. Table 1 reports the minimum and maximum number of yearly observations within $+/-40 \%$ of the relevant population over the period 1998 to 2011 . We also report the figure for the 10,000 threshold, as we use this in our robustness check. The table shows that the municipality size distribution is highly skewed, with the number of relevant observations decreasing rapidly as we move to the upper thresholds. Note that the empirical methods we employ here were developed in the context of millions of individual tax returns (see, for example, Chetty et al., 2011 and Kleven and Waseem, 2013), and, thus, they rely on thick densities. Since we study municipalities instead of individuals, and despite reporting some results for both 10,000 and 20,000 inhabitants, we primarily focus on the 5,000 threshold as it provides us with the highest number of observations possible. To plot the data, we use $1 \%$ bins, which results in 50 inhabitants-groups per bin at the 5,000 threshold, 100 inhabitants-groups per bin at the 10,000 threshold, and 200 inhabitants-groups per bin at the 20,000 threshold. Since we include the range of $+/ 40 \%$, we have 40 bins to the left and another 40 bins to the right of each threshold.

[Table 1 about here]

\section{Results}

\subsection{Baseline estimates - Bunching at the 5,000-inhabitant threshold}

In this section we identify and quantify bunching behavior at the 5,000-inhabitant threshold. Panel a) in Figure 6 serves as the empirical counterpart of Figure 5, used in illustrating the empirical methodology. The (appropriately binned) data show the empirical density and provide strong (suggestive) evidence that there are too many (few) municipalities to the right (left) of the threshold.

[Figure 6 about here]

Panel b) in Figure 6 shows the McCrary (2008) test and confirms that, indeed, the empirical density is not continuous at the 5,000-inhabitant threshold. Panel a) in Figure 6 also reports $r_{L}$ and $r_{U}$, which determine the excluded range, while the solid line is the counterfactual density obtained if a second-order polynomial is specified (i.e. $q=2$ ). The corresponding bunching estimates are reported in Table 2.

[Table 2 about here]

$r_{U}$ is chosen by visual inspection at 5,800 inhabitants, which is the first time that the empirical density crosses the threshold of the counterfactual density. Summing up the difference between the empirical and counterfactual densities between $\hat{r}$ and $r_{U}$ delivers $B$, the excess number of municipalities above the threshold. There are 362 municipalities that would be below 5,000 inhabitants in the absence of the notch. The standard error of $B$ is 79.52, indicating 
that $B$ is statistically significant. Remember that we choose $r_{L}$ (3,850 in our application) to equate $B$ and $M$; that is, the excess mass between $\hat{r}$ and $r_{U}$ must equal the missing mass between $r_{L}$ and $\hat{r}$. Hence, the number of missing observations below 5,000 inhabitants is also 362 municipalities. The fact that the density hole disappears at 3,850 inhabitants indicates that the most responsive municipalities over-report around 1,150 inhabitants. However, most municipalities did not respond to the bunching incentives. Summing the counterfactual density between 3,850 and 5,000 inhabitants gives us the number of municipalities between $r_{L}$ and $\hat{r}$ that would be observed in the absence of the notched transfer schedule. Dividing B by this number gives us the fraction of respondents. Only about $10 \%$ of all municipalities that would be in the 3,850-5,000 range crossed the 5,000 threshold to receive higher per capita grants.

In the density hole area, we know the counterfactual $\left(\widetilde{c_{j}}\right)$ and observed $\left(c_{j}\right)$ municipality counts in each bin $j$. Hence, we can compute the proportion of respondents in each bin as well as the reported population increase for those that responded; that is, $\hat{r}-r_{j}$. Hence, the average response amounts to:

$$
d r=\sum_{j=r_{L}}^{\hat{r}} \tilde{w}_{j} \frac{\left(\widetilde{c_{j}}-c_{j}\right)}{\widetilde{c_{j}}}\left(\hat{r}-r_{j}\right)
$$

where $\tilde{w}_{j} \equiv \frac{\widetilde{c_{j}}}{\sum_{j=r_{L}}^{\hat{c_{j}}}}$ is the share of counterfactual observations in each bin within the missing mass area.

Our bunching estimates imply that, on average, the notch increases over-reported population by 62 inhabitants. Note that this is more than ten times smaller than the effect found for the most responsive individuals and is consistent with the fact that, between $r_{L}$ and $\hat{r}$, only about $10 \%$ of municipalities respond to the incentives to over-report created by the notch. As shown in Section 3, a measure of the density hole along with the change in grants induced by the notched schedule can be used to compute the elasticity of reported population to grants. We measure two different elasticities of reported population to grants. Our first measure uses the lower bound of reported population $r_{L}$ to identify the elasticity of reported population to grants of the most responsive municipalities:

$$
\epsilon_{r_{L}, \alpha}=\frac{\frac{\hat{r}-r_{L}}{r_{L}}}{\frac{\hat{r}}{\hat{r}-r_{L}} \frac{\beta}{\alpha}}
$$

Recall that the numerator is the percentage increase in reported population when moving from $r_{L}$ to $\bar{r}$. In our application this percentage is $29 \%$. As for the denominator, recall that moving from 5,000 to 5,001 increases per capita grants by 85,000 euros (i.e., $\bar{r} \beta$ ). This increase becomes smaller for municipalities the further they are away from 5,001. For $r_{L}$, moving from 3,850 to 5,001 increases per capita grants by about $73 \%$. As a result, the elasticity of over-reported population to grants is around $40 \%$ for the most responsive municipalities. Our second measure 
reflects the average elasticity which amounts to:

$$
\epsilon_{r, \alpha}=\sum_{j=r_{L}}^{\hat{r}} \tilde{w}_{j} \frac{\left(\widetilde{c_{j}}-c_{j}\right)}{\widetilde{c_{j}}} \frac{\frac{\hat{r}-r_{j}}{r_{j}}}{\frac{\hat{r}}{\hat{r}-r_{j}} \frac{\beta}{\alpha}}
$$

The results indicate that the average elasticity is about 0.013 . The two elasticities imply that doubling per capita grants would increase reported population by 40 and 1.3 per cent for the most responsive and the average municipality, respectively. Hence, one implication of our results is that there is a large degree of heterogeneity in the responsiveness of municipalities to grants, which compromises the fairness of grant allocation. A municipality with a real population of 3,850 inhabitants and which over-reports 1,251 inhabitants (that is, a reported population more than $25 \%$ higher than its real population) obtains $50 \%$ more resources per 'real' resident than a municipality that has and reports 3,850 inhabitants.

Columns 2 to 5 in Table 2 assess the robustness of the bunching estimates to the specification of bin size and polynomial order. In columns 2 and 3 we report the estimates obtained when the densities are estimated grouping the observations in bin sizes of 40 and 60, respectively. This exercise shows that the results are not sensitive to the choice of the bin size. The baseline results are obtained by estimating the counterfactual density using a quadratic polynomial. Note that Figure 6 suggests that a second-order polynomial fits the empirical density well (which is corroborated by the Akaike information criterion). Nevertheless, to assess if the results are sensitive to this particular parametrization, we re-estimate the bunching using polynomials of order 3 and 4 . The results, reported in columns 2 and 3 in Table 2 indicate that our results are robust to using higher-order polynomials, too.

At this juncture, however, it is interesting to verify whether the estimated elasticities are large enough to give rise to concerns about the problem under study. Obviously, the marginal elasticity of 0.40 illustrates just how severe the effects could be for a municipality facing extreme levels of opportunities and incentives to cheat. Thus, even if this value is not representative on average, it is a clear reminder that with imperfect auditing a municipality may massively over-report its number of residents. An average elasticity of 0.013 is the figure that can be considered most representative of the global effects of population over-reporting. For instance, let's assume for a moment that this elasticity is extrapolated to include the whole universe of Spanish municipalities. If we take the total amount of transfers allocated in 2001 (around 2,850 million euros), an elasticity of this dimension would mean that around 40 million euros were misallocated (i.e., $0.013 \cdot 2,850$ ); that is, that an extra 40 million euros would have had to be added to the pot of transfers in order to ensure a similar amount of transfers (per real resident) as that which would be available in a situation without manipulation. Although the impact on the level of transfers enjoyed by a typical (non over-reporting) municipality is not that great, 40 million euros is by no means negligible. Indeed, it would be interesting to compare this figure 
with the cost of improving the audit technology in order to put an end to this problem. In reality, this task is far from easy given the general lack of information within the INE regarding budgeting and the use of resources. However, in order to gauge the magnitude of the problem at hand, the 40 million euros can be compared to the cost of running a census (which can be considered a quasi-perfect audit, see next section), which was calculated at 162 million euros in 2001 (and given the ten-year interval between censuses, this works out at c. 16 million per year, source: www.ine.es). Obviously, a census would be carried out even if there were no over-reporting of population, so the amount actually needed to keep this problem in check is probably much lower than the savings at stake.

\subsection{Bunching with improved enforcement over time}

As outlined in Section 2, INE monitoring has improved over time. Municipalities were required to clean up their registers based on the results of the 2001 census. These operations were extended until the end of 2004. Subsequently, in 2005, to deal with problems related to the underreporting of out-migration and the double-counting of immigrants, the INE obliged non-EU immigrants to renew their registration every second year. In practice, all immigrants registered before December 2003 that failed to re-register were deleted from the register in December 2005. Thus, overall, we expect the opportunities to over-report population to be greater during the first years of our sample. To determine whether bunching is less evident with better monitoring, we split our sample into two different sub-periods (1998-2005 and 2006-2011). Figure 7 shows the bunching patterns for these two sub-periods in panels a) and c) together with the relevant McCrary (2008) test results in panels b) and d).

\section{[Figure 7 about here]}

Figure 7 reveals that, indeed, bunching patterns are stronger during the sub-period in which INE monitoring was less effective. In fact, although there seems to be an excess of mass to the right of the 5,000-inhabitant threshold in the two sub-periods, the McCrary (2008) test cannot reject the hypothesis that the density is continuous for the 2006-2011 period. The bunching estimates also suggest that manipulating population numbers was more prevalent in the earlier period. In the period 1998-2005, the excess density to the right of the 5,000-inhabitant threshold totaled 155 observations while it reached just 35 in the period 2006-2011 period. ${ }^{10}$ Hence, our results seem to confirm that weaker institutions give local governments more room to manipulate their population figures.

\footnotetext{
${ }^{10}$ Note that this exercise is not one of decomposition, as $r_{U}$ is chosen by visual inspection in each sub-period. It turns out that $r_{U}$ is smaller in each of the two sub-periods than it is for the entire period.
} 


\subsection{The 2001 Census as an 'audit' operation}

Our results clearly indicate that too many municipalities lie above the threshold but, up to this juncture, we have not specifically identified the type of municipalities that tend to overreport their population figures. The 2001 census was the last field operation (including visits to all households) to produce municipal population figures (with base date November 2001) and can be considered to be a faithful reflection of the 'real' population (Jurado, 2004). This means that comparing the census and registered figures can be informative about the characteristics of the municipalities that manipulated their population data. Focusing on the sample of municipalities that report a population level between $\hat{r}$ and $r_{U}$, we estimate the probability of a municipality reporting a population greater than 5,000 inhabitants in January 2002 while the census reported a population below 5,000 in November 2001. In the logistic regressions that we report, we control for the distance between reported population and the 5,000-inhabitant threshold. We also control for population growth between 2000 and 2001 to proxy for the potential 'real' growth occurring between November 2001 and January 2002. The marginal effects implied by the estimates (which do not hinge on the inclusion or otherwise of these two controls) are reported in Table 3.

\section{[Table 3 about here]}

Among the municipal characteristics analyzed, we first consider factors that reflect differences in over-reporting opportunities. In terms of the model presented in Section 3, these differences would correspond to heterogeneous detection probabilities (the $\gamma$ 's). Specifically, we include the \% of foreigners in 2001 (column 1) and the \% of second homes in 2001 (column 2). In column 3, we consider population turnover, defined as the sum of in- and out-migration rates in the period 1991-2001, to recognize that municipalities with a more mobile population might have more chances to inflate population numbers.

Next, we consider political variables to proxy for differences in the incentives to over-report, related to the (political) cost of being caught over-reporting population (the $\theta$ 's in Section 3 ). In column 4, we introduce the vote turnout in the 2000 national elections. We do so because in places with a higher turnout, the level of civic capital of the population is higher (Putnam, 1993) and, thus, residents would not agree to report misleading population figures (even if this were to benefit the town in terms of extra transfers). There is a vast literature supporting the idea that tax compliance is higher in places with higher 'tax morale' (Slemrod, 2007), and some recent papers documented that tax enforcement is also higher in places with more social capital (see e.g., Casaburi and Troiano, 2015, and Besley, Jensen, and Persson, 2015). In column 5, we consider the incumbent vote share in the last municipal elections (see Besley, Persson, and Sturm, 2010). We do so because an incumbent that won the election with a very small share of the vote is likely to feel less safe and to understand that being caught manipulating population numbers is likely to undermine their reputation, thus destroying their chances of reelection 
when no more than a few votes are needed to change the outcome (see Solé-Ollé (2006) and Solé-Ollé and Viladecans-Marsal (2012), for evidence that local incumbents in Spain are sensitive to these incentives). ${ }^{11}$

In column 6, we introduce an indicator variable partisan alignment that takes a value of one if the mayor belongs to Partido Popular, the party in office at the national level during the period 1996-2004. We do so to test if, as Litschig (2012) has documented for Brazil, the over-reporting of population is higher in municipalities that are aligned with the central government. Note that in contrast to Brazil, in Spain, local population figures are reported by municipalities. Nevertheless, it could well be that the central government dedicates less effort to monitoring aligned municipalities. In columns 7, 8 and 9, we include fiscal incentives to determine whether over-reporting is related to situations of fiscal distress. Specifically, we test if municipalities with high debt service (column 7) or high rates of property tax (column 8) or business tax (column 9) cheat more often. Finally, column 10 reports the results of a regression in which manipulation opportunities, political variables and fiscal incentives are jointly considered.

Focusing on this last and more complete specification, the results underline the importance of both manipulation opportunities and political cost-related incentive channels. ${ }^{12}$ Thus, municipalities with a high \% of foreigners are more likely to manipulate the population register. This is consistent with the fact that the probability of detection should be lower if the residents being over-reported are foreigners. The estimates imply that a one percentage point increase in this variable increases the probability of a municipality having over-reported its population so that it surpasses the 5000 -threshold by 0.17 . The impact of the other variables reflecting increased manipulation opportunities are much smaller and are found to be statistically insignificant.

In the case of variables reflecting differences in the political costs of manipulation, municipalities with more civic capital (reflected in a higher voter turnout in national elections) are less likely to manipulate population numbers. Specifically, a one percentage point increase in turnout decreases the probability of being caught manipulating population numbers by 0.027 . Similarly, municipalities in which the position of the incumbent is relatively secure (measured by the incumbent vote share in the last local elections) are more likely to cheat. Here, one additional percentage point in the margin of victory increases that probability by 0.03 .

As for the political alignment variable, the point estimate indicates that municipalities with a

\footnotetext{
${ }^{11}$ Of course, this presumes that voters dislike the manipulation of population numbers by local population. In the event this was not the case - because of a very low level of social capital - this prediction would not hold. Actually, we would expect that a high level of political competition would encourage over-reporting. The empirical results will tell us whether this is the case or not.

${ }^{12}$ The inclusion of the \% of foreigners seems to be particularly important in terms of statistical significance and its exclusion confounds the effects of the second home and incumbent's vote share variables. The incumbent's vote share coefficient is statistically insignificant when the \% of foreigners is excluded, suggesting that the effect was driven by the correlation between these two variables.
} 
mayor belonging to the conservative Partido Popular are more likely to over-report population figures, suggesting that the central government tends to monitor more closely unaligned (i.e. left-wing) municipalities. Finally, we find no evidence that more indebted municipalities or those that set higher local tax rates cheat more, indicating that manipulation is not driven by the need for fiscal resources.

\subsection{Real population responses?}

In the theoretical model outlined in Section 3, we focused on one type of response to the incentives created by the transfer schedule, i.e., reporting population numbers that are larger than the number of real residents in the municipality. Besides the ample anecdotal evidence suggesting that this has been the main margin of adjustment in the Spanish case, two sets of results identify manipulation as the main mechanism underlying bunching behavior. First, as shown in Figure 7, as monitoring has improved over time (and detection probabilities have increased), the amount of bunching has decreased. Second, the results reported in Table 3 support the predictions of the over-reporting model presented in Section 3, that is, that local governments cheat if they have the opportunity to do so (because they have more foreign residents) and if the political costs in case of being caught are low (low voter turnout and/or because the incumbent clearly won the last election).

However, municipalities might also respond by, for instance, enacting more expansionary zoning policies or offering fiscal benefits to newcomers. While there is some anecdotal evidence for both types of effort, there are reasons to believe that they might not constitute effective strategies. ${ }^{13}$ In any case, we can directly test if municipalities respond to transfers by increasing their real population figures by determining whether the density of census population around the 5,000-inhabitant threshold is smooth or not. The appropriate McCrary (2008) tests are presented in Table 4 and in Figure 8. The non-significance of these tests provides further evidence for the fact that manipulation is the main driver of the bunching patterns observed.

[Figure 8 and Table 4 about here]

\subsection{Bunching at the 20,000 threshold}

As discussed above, the techniques used in this paper have been developed to analyze the thick densities of individual tax returns. For this reason, the paper has focused primarily on the first

\footnotetext{
${ }^{13}$ Note that in Spain this responsibility lies fully with the local governments. There is ample evidence that the preferences of voters and politicians determine the amount of developable land and other zoning instruments (see, e.g. Solé-Ollé and Viladecans-Marsal, 2012, 2013). Further, there is some anecdotal evidence that municipalities affected by a possible downgrade in their population category make some efforts to attract new residents (e.g., the town of Cardona - mentioned above - offered subsidized housing (see "Cardona takes action to find more residents", in La Vanguardia 8/12/2014, www.lavanguardia.com); in the same article, however, the mayor regrets that these measures have been adopted too late.
} 
population threshold fixed at 5,000 inhabitants. However, in this subsection we analyze the bunching that occurs at the 20,000-inhabitant threshold. The results are presented in Figure 9. Panel a) shows the bunching metrics developed in Section 4.1 while panel b) reports the corresponding McCrary (2008) test results. Table 5 summarizes the information in a similar way as to that used for the 5,000-inhabitant threshold.

[Table 5 and Figure 9 about here]

The McCrary (2008) test indicates that the density is not continuous at the 20,000 threshold and that it is higher just above that threshold. The bunching estimates imply that the counterfactual density is distorted between 19,801 and 20,201 inhabitants. The estimate for $\mathrm{B}$, that is, the number of municipalities above 20,000 inhabitants that should be below this threshold, is 18.36. The standard error of $B$ is 10.001 which yields a p-value of 0.06 . Recall that $B$ is also the missing number of municipalities between 19,801 and 20,000 inhabitants $(M)$. B amounts to 0.33 of the counterfactual density in the 19,801-20,000 range, and gives us the fraction of municipalities that respond to the incentives to bunch. In terms of responses, the most elastic municipalities over-report around 200 inhabitants, while the average response $(d r)$ is 72 . The corresponding elasticities are 0.002 and 0.0003 for the most responsive and the average municipality, respectively. Although this exercise might have limited power, the results obtained imply that the responses are relatively smaller than those obtained for the 5,000-inhabitant threshold. Note that while the density hole disappears at a point that is 200 inhabitants below the 20,000 threshold, the empirical density was below the counterfactual density at 3,850 inhabitants in the case of the analysis of the 5,000-inhabitant threshold. The results also suggest that there is less heterogeneity in the responses at the 20,000 threshold, with a third of municipalities responding, compared to the 10 per cent recorded at the 5,000 threshold. Interestingly, the average number of over-reported inhabitants is very similar in both cases: 62 and 72 in the 5,000- and 20,000-inhabitant thresholds, respectively. This is consistent with most municipalities being able to over-report, if needed, a few score of inhabitants irrespective of their size (rather than a fixed proportion of their population), as these individuals can be attributed to mistakes or randomness. A further, complementary, explanation might be that the INE monitors large municipalities more intensely, given that small municipalities are more expensive to monitor in per capita terms.

\subsection{Other policy discontinuities?}

As discussed by Eggers et al. (2015), it is often the case that several policies are subject to change at a given population threshold. Although anecdotal evidence from the municipalities engaged in manipulation indicates that in practice increased transfers are the only advantage considered, there are three other institutional arrangements that change at the 5,000-inhabitant 
threshold: spending responsibilities, maximum tax rates and council size. Below, we address each of these discontinuities in turn.

We are confident that no other institutional features change at this threshold as policydiscontinuities are easily identified by analyzing the (highly centralized) political and financial framework of local governments. ${ }^{14}$ The work of local governments is covered by two national laws, the aforementioned legislation regulating municipal finances and a law that regulates the administrative and political workings of local government (the Law 7/ 1985 Reguladora de Bases de Régimen Local).

\section{Spending responsibilities}

The 1988 law regulating local government finances also establishes the spending responsibilities for each municipality size class. Besides the goods and services that all municipalities are required to provide, those exceeding 5,000 inhabitants also have to provide public parks, waste treatment, sports facilities and a library. Note that this was the historical rationale for the increase in per capita transfers at this population threshold. Panel a) of Figure 10 shows the evolution of per capita spending in these items at the 5,000-inhabitant threshold.

[Figure 10 about here]

The data, however, show that public spending on public parks, waste treatment, sports facilities and libraries does not increase at the 5,000-inhabitant threshold. In fact, the application of this regulation is not at all stringent, partly because upper-level governments do not provide these services for the smallest municipalities. In practice, municipalities only start to provide these services when citizens actively demand them, and this clearly depends both on preferences and resources, which vary widely across municipalities. ${ }^{15}$ Economies of scale are undoubtedly important too, with municipalities only starting to provide these additional services when they reach a minimum population size, which might be highly heterogeneous and does not need to coincide with the 5,000 threshold. In fact, what we observe is that per capita spending on these items grows continuously with population.

\section{Maximum tax rates}

Until 2002, the property and local business taxes could be fixed at a higher rate in those municipalities exceeding the 5,000-inhabitant threshold. In the case of the property tax, the incentive

\footnotetext{
${ }^{14}$ See (Eggers et al., 2015) for a discussion of this point. In contrast to other countries, the mayor's pay (Gagliarducci and Nannicini, 2013) or the fiscal oversight framework (Grembi, Nannicini, and Troiano, 2012) did not depend directly on municipality size in the years included in our study. A reform, passed in January 2014, introduced pay caps in municipal governments that differ across municipality sizes, as well as other changes regarding the personnel management.

${ }^{15}$ As mentioned, the equalization power of transfers to local governments is null, which means there are major revenue differences between the municipalities.
} 
was not binding because a municipality charging the maximum nominal tax rate could always choose to reappraise property values. While it might be quite difficult to present this to the citizens as a benefit, the question might be raised as to whether municipalities under fiscal distress inflate their population figures to surpass the 5,000 threshold and so increase local business tax rates. However, the results reported in Table 3 suggest that this is not the case as the typical municipality that over-reports its figures is not indebted and does not levy high local tax rates. All in all, maximum tax rates do not seem to account for the observed bunching patterns and, reassuringly, we have not met any local incumbent that mentions this possibility.

\section{Council size}

The number of representatives sitting on the Council increases from 11 to 13 at the 5,000inhabitant threshold. In principle, council size could well increase (rather than decrease) council fragmentation and, thus, we would expect incumbent governments to bunch to the left (rather than to the right) of the 5,000 threshold to avoid having to share power in a coalition or a minority government (see e.g. Fiva and Folke, 2014). Moreover, there are two pieces of evidence that indicate that council size is actually not confounding our results.

First, the change in council size at the 5,000-inhabitant threshold is not large enough to have any great impact on council fragmentation. Panel b) of Figure 10 plots the share of local councils which operate with a majority around the 5,000 threshold. No significant change is recorded in the percentage of councils with a majority government, indicating that fragmentation does not significantly increase at the 5,000-inhabitant threshold.

Second, at the 10,000-inhabitant threshold, council size increases from 13 to 17 seats while per capita grants remain constant. Hence, studying bunching at the 10,000 threshold is an indirect way of testing if council size explains the bunching patterns that have been documented at the 5,000 and 20,000 thresholds. The results for the 10,000-inhabitant threshold are presented in column b) of Table 5 and illustrated in Figure 11.

[Figure 11 about here]

Both, the bunching estimates (Panel a) and the McCrary (2008) test (Panel b) do not find statistically significant evidence of bunching behavior at the 10,000 threshold. Taken together with the 20,000 threshold analysis, the 10,000-inhabitant threshold results provide further evidence that the increase in per capita grants (rather than an increase in council size) is the underlying cause of bunching.

\section{Conclusion}

In this paper we have analyzed the notches generated by a transfer system to local governments. We find significant evidence that the incentives generated by the grant schedule result 
in the manipulation of population figures. Municipalities, which are responsible for the registration of local residents, systematically inflate their population figures, thereby making them eligible for higher per capita transfers. Specifically, we found a missing mass of around $10 \%$ of the municipalities to the left of the 5,000-inhabitant threshold, where transfers per capita jump discretely. Municipalities in this range over-report by an average of 60 more residents than those actually living in the town. However, in some municipalities the number of 'ghost' residents reaches 1,000 . The effect of this over-reporting of population on the amount of transfers for those municipalities that opt not to misbehave is not dramatic (we estimate a figure between one and two percentage points). However, in absolute terms, the amount of misallocated transfers is far from negligible (again we estimate a figure of around 40 million euros for 2001), which suggests more resources should be assigned to audit policies. Indeed, we find evidence that enhanced audit policies are effective in curbing this problem. For instance, we found that bunching disappeared after the INE introduced several audit improvements (including, for example, using the census to cleanse the population register, and requiring foreigners to re-register every two years). Our analysis of the discrepancies between the census and the register also reveals that the municipalities more prone to over-reporting are those in which there are greater opportunities (more foreigners and second homes) and incentives (less civic capital and electoral competition) to do so. These results are consistent with the predictions of the model presented in this paper and also suggest that the reason municipalities bunch to the right of the transfer thresholds is population over-reporting. Moreover, the fact that we find no bunching in census figures is further proof that municipalities do not respond to transfers by attracting more residents (or if they do so, they are largely ineffective).

The general conclusion to be drawn from our results is that even very simple formula transfers (such as those based on population) can be manipulated by recipients if their collaboration is needed in supplying information and the control policies operated by the central government are imperfect. While it is true that the size of the effects that we find are not especially great (the loss of resources is not dramatic, even without proper auditing systems) and that the problem was resolved when the national government intervened, they nevertheless serve as a warning to governments and consultants advising on similar transfer systems in developing countries - if the system can be manipulated in a developed country (with a modern, albeit inefficient, administration and a certain level of civic capital), what might happen in less favorable environments? 


\section{References}

Bahl, Roy. 2000. "Intergovernmental Transfers in Developing and Transition Countries: Principles and Practice." Background Series 21097, The World Bank.

Besley, Timothy and Torsten Persson. 2013. “Taxation and Development." In Handbook of Public Economics, Handbook of Public Economics, vol. 5, edited by Martin Feldstein Alan J. Auerbach, Raj Chetty and Emmanuel Saez. Elsevier, $51-110$.

Besley, Timothy, Torsten Persson, and Daniel M. Sturm. 2010. "Political Competition, Policy and Growth: Theory and Evidence from the US.” The Review of Economic Studies 77 (4):13291352.

Besley, Timothy J., Anders Jensen, and Torsten Persson. 2015. “Norms, Enforcement, and Tax Evasion.” C.E.P.R. Discussion Papers 10372, Centre for Economic Policy Research.

Bird, Richard M. and Michael Smart. 2002. "Intergovernmental Fiscal Transfers: International Lessons for Developing Countries.” World Development 30 (6):899-912.

Bird, Richard M. and Eric M. Zolt. 2008. “Technology and Taxation in Developing Countries: From Hand to Mouse." National Tax Journal 61 (4):791-821.

Boex, Jameson and Jorge Martínez-Vázquez. 2007. "Designing intergovernmental equalization transfers with imperfect data: concepts, practices, and lessons." In Fiscal equalization: challenges in the design of intergovernmental transfers, edited by J. Martínez-Vázquez and Bob Searle. Springer, 291-343.

Bordignon, Massimo, Paolo Manasse, and Guido Tabellini. 2001. "Optimal Regional Redistribution under Asymmetric Information.” American Economic Review 91 (3):709-723.

Casaburi, Lorenzo and Ugo Troiano. 2015. "Ghost-House Busters: The Electoral Response to a Large Anti Tax Evasion Program." Quarterly Journal of Economi forthcoming.

Chetty, Raj, John N. Friedman, Tore Olsen, and Luigi Pistaferri. 2011. "Adjustment Costs, Firm Responses, and Micro vs. Macro Labor Supply Elasticities: Evidence from Danish Tax Records.” The Quarterly Journal of Economics 126 (2):749-804.

Dixit, Avinash and John Londregan. 1995. "Redistributive Politics and Economic Efficiency." The American Political Science Review 89 (4):pp. 856-866.

Eeckhout, Jan. 2004. “Gibrat's Law for (All) Cities.” American Economic Review 94 (5):14291451. 
Eggers, Andrew C., Ronny Freier, Veronica Grembi, and Tommaso Nannicini. 2015. "Regression Discontinuity Designs Based on Population Thresholds: Pitfalls and Solutions.” Discussion Papers 1503, DIW Berlin.

Fisman, Raymond and Shang-Jin Wei. 2004. "Tax Rates and Tax Evasion: Evidence from "Missing Imports" in China." Journal of Political Economy 112 (2):471-500.

Fiva, Jon H. and Olle Folke. 2014. "Mechanical and Psychological Effects of Electoral Reform.” British Journal of Political Science forthcoming.

Foremny, Dirk. 2014. "Sub-national deficits in European countries: The impact of fiscal rules and tax autonomy." European Journal of Political Economy 34 (0):86 - 110.

Gabaix, Xavier. 1999. “Zipf's Law For Cities: An Explanation.” The Quarterly Journal of Economics 114 (3):739-767.

Gagliarducci, Stefano and Tommaso Nannicini. 2013. "Do better paid politicians perform better? Disentangling incentives from selection.” Journal of the European Economic Association 11 (2):369-398.

Grembi, Veronica, Tommaso Nannicini, and Ugo Troiano. 2012. “Policy Responses to Fiscal Restraints: A Difference-in-Discontinuities Design.” IZA Discussion Papers 6952, Institute for the Study of Labor.

Huber, Bernd and Marco Runkel. 2006. “Optimal Design of Intergovernmental Grants Under Asymmetric Information.” International Tax and Public Finance 13 (1):25-41.

Jurado, Ana. 2004. “Diferencias entre Censo de Población y Padrón Municipal.” Índice - Revista de Estadística y Sociedad 3 (3):12-13.

Kim, Junghun and Jorgen Lotz. 2008. Measuring Local Government Expenditure Needs - The Copenhagen Workshop 2007. The Korea Institute of Public Finance and the Danish Ministry of Social Welfare.

Kleven, Henrik J. 2016. “Bunching.” Annual Review of Economics .

Kleven, Henrik J., Martin B. Knudsen, Claus Thustrup Kreiner, Sï $\AA^{1 / 2}$ ren Pedersen, and Emmanuel Saez. 2011. "Unwilling or Unable to Cheat? Evidence From a Tax Audit Experiment in Denmark." Econometrica 79 (3):651-692.

Kleven, Henrik J. and Mazhar Waseem. 2013. "Using Notches to Uncover Optimization Frictions and Structural Elasticities: Theory and Evidence from Pakistan.” The Quarterly Journal of Economics 128 (2):669-723. 
Litschig, Stephan. 2012. "Are rules-based government programs shielded from special-interest politics? Evidence from revenue-sharing transfers in Brazil.” Journal of Public Economics 96 (1144):1047-1060.

McCrary, Justin. 2008. "Manipulation of the running variable in the regression discontinuity design: A density test." Journal of Econometrics 142 (2):698-714.

Oates, Wallace E. 1972. Fiscal federalism. New York: Harcourt Brace Jovanovich.

—. 1999. “An Essay on Fiscal Federalism.” Journal of Economic Literature 37 (3):1120-1149.

Persson, Torsten and Guido Tabellini. 2002. Political Economics: Explaining Economic Policy. MIT Press Books. The MIT Press.

Putnam, Robert. 1993. Making Democracy Work: Civic Traditions in Modern Italy. New Jersey: Princeton University Press.

Saez, Emmanuel. 2010. “Do Taxpayers Bunch at Kink Points?” American Economic Journal: Economic Policy 2 (3):180-212.

Slemrod, Joel. 2007. “Cheating Ourselves: The Economics of Tax Evasion.” Journal of Economic Perspectives 21 (1):25-48.

— 2010. "Buenas Notches: Lines and Notches in Tax System Design." University of Michigan Workin Paper .

Solé-Ollé, Albert. 2006. “The effect of party competition on budget outcomes: empirical evidence from local governments in Spain.” Public Choice 126 (1-2):145-176.

Solé-Ollé, Albert and Núria Bosch. 2005. "On the Relationship between Authority Size and the Costs of Providing Local Services: Lessons for the Design of Intergovernmental Transfers in Spain.” Public Finance Review 33 (3):343-384.

Solé-Ollé, Albert and Elisabet Viladecans-Marsal. 2012. "Lobbying, political competition, and local land supply: Recent evidence from Spain.” Journal of Public Economics 96 (1-2):10 -19.

— 2013. "Do political parties matter for local land use policies?" Journal of Urban Economics $78(\mathrm{C}): 42-56$.

Wildasin, David E. 1986. Urban Public Finance. Routledge.

Yitzhaki, Shlomo. 1987. “On the Excess Burden of Tax Evasion.” Public Finance Review 15 (2):123-137. 


\section{Graphs and tables}

Figure 1: Distributed grants in 2005

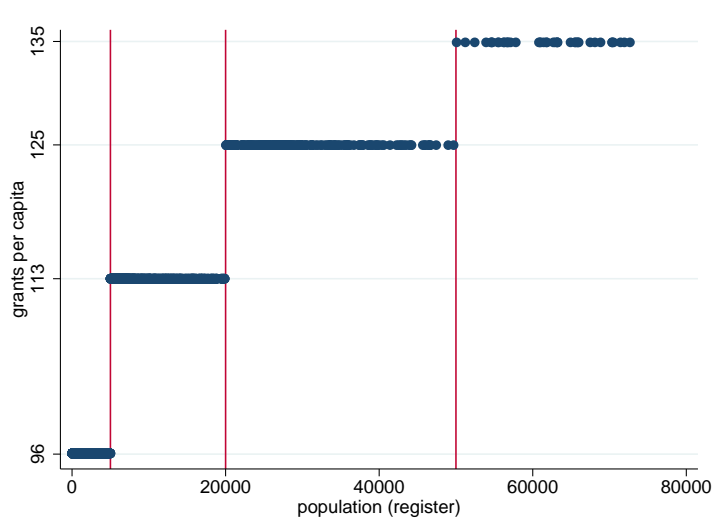

(a) grants per capita

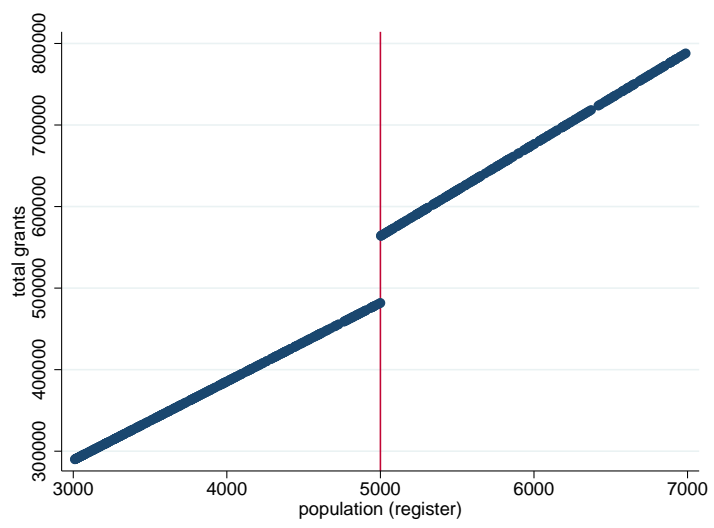

(b) grants in absolute values

Notes: 75\% of PIE allocated according to population figures per inhabitant. Data for 2005.

Figure 2: Utility with a notched transfer scheme

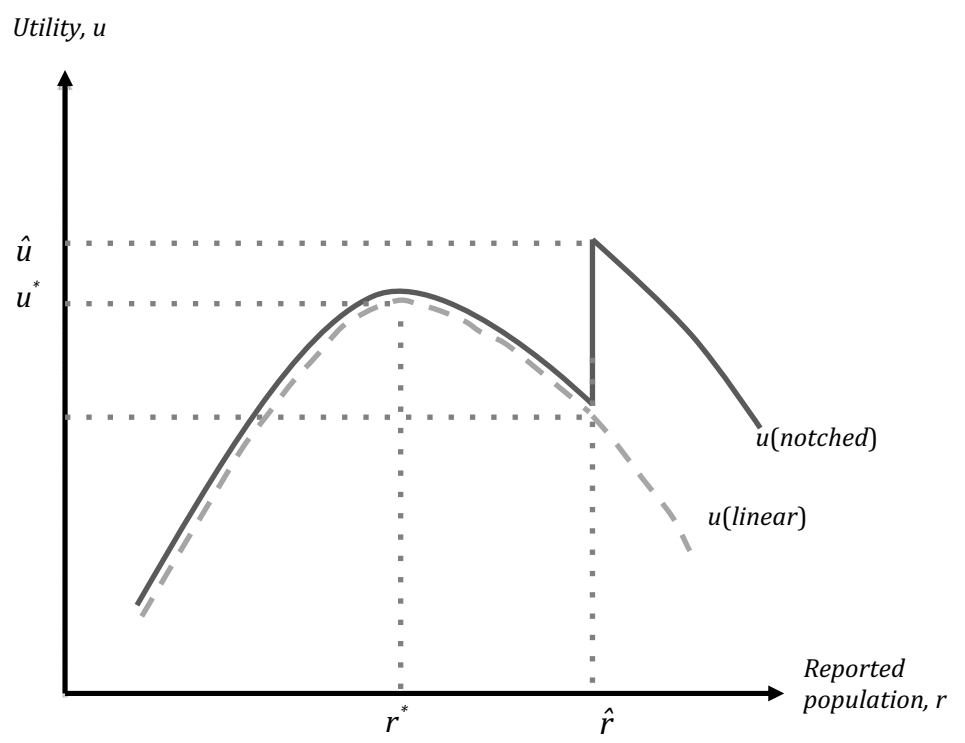


Figure 3: Effect of a notched transfer scheme on reported population density Utility, $u$

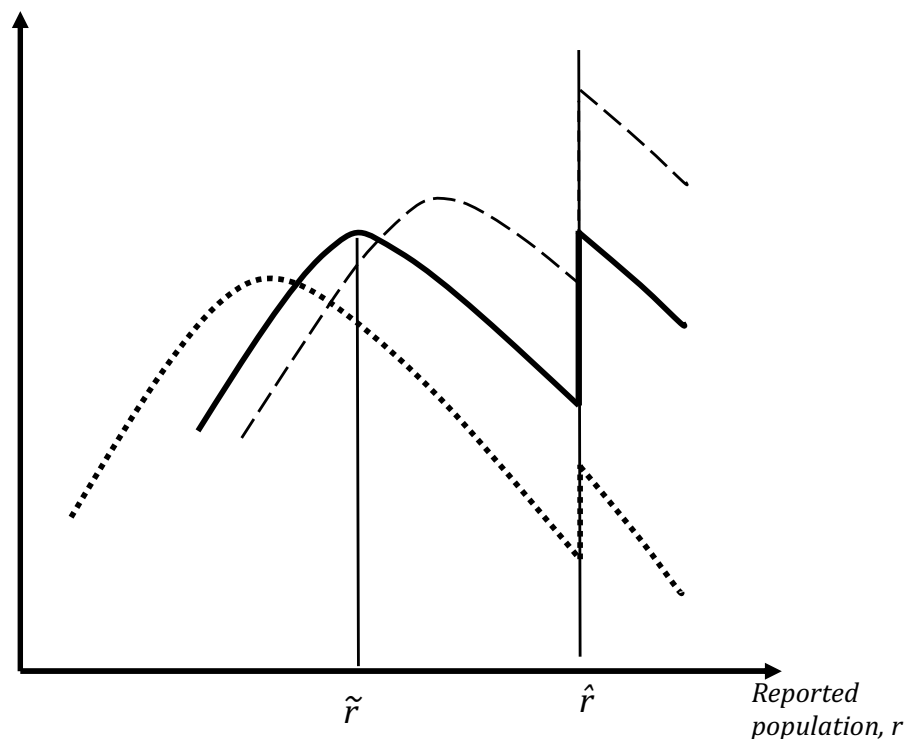

(a) Utility

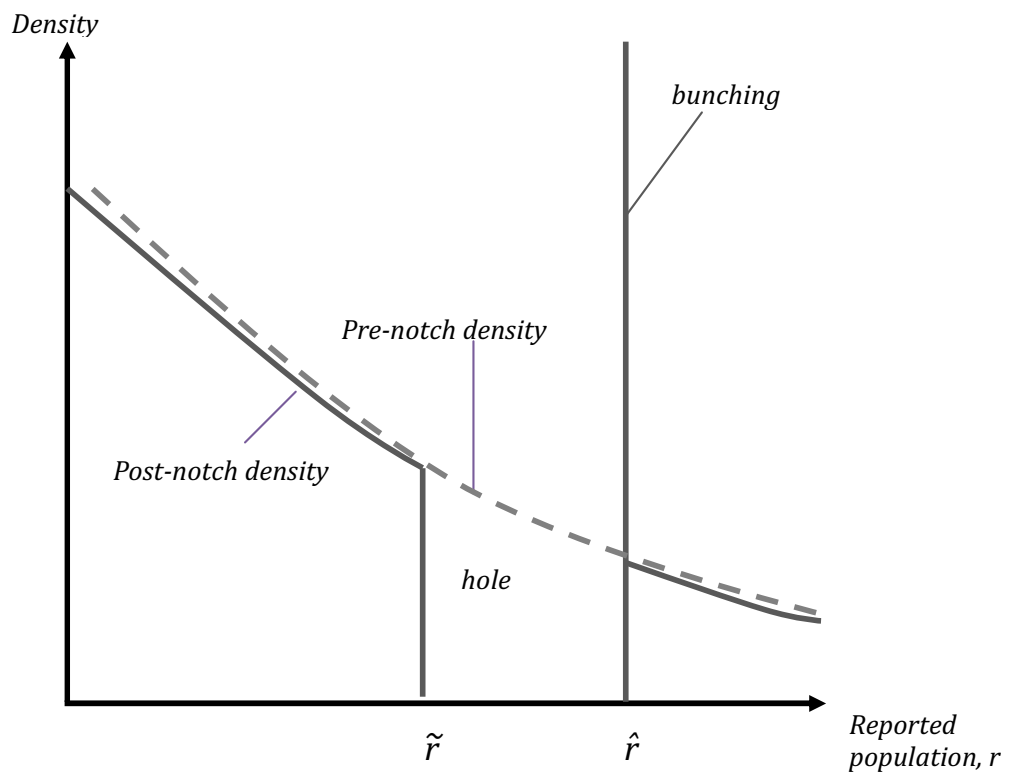

(b) Density function 
Figure 4: Bunching in the presence of heterogeneity and shocks

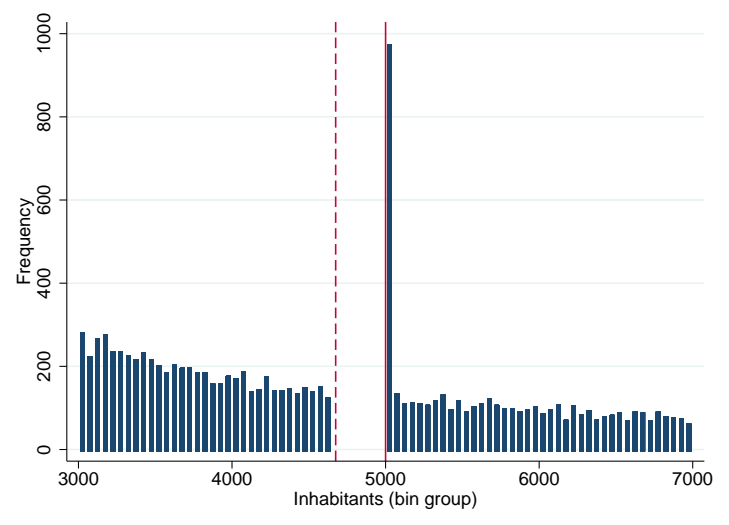

(a) Baseline case

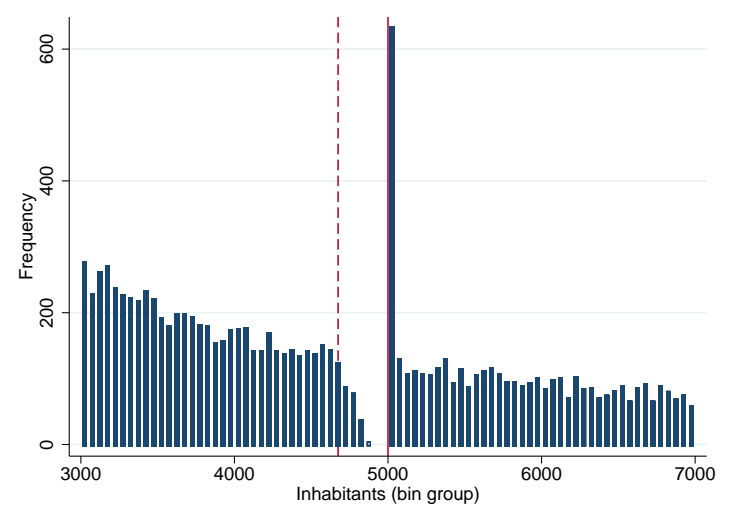

(b) Heterogeneity

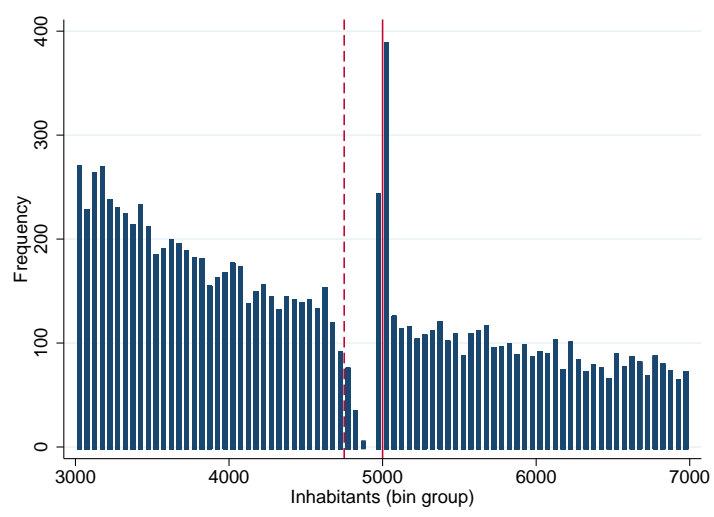

(c) Shocks and Heterogeneity

Notes: Simulation based on 100k draws. $n$ drawn from a log-normal distribution with mean and standard deviation equal to 6.458 and 1.840. $\alpha, \beta, \theta$ equal to $100,16,400$. In panel a, $\gamma$ is -0.1 while $\gamma_{i} \sim U(-0.2,-0.1)$ in Panels (b) and (c). In Panel (c), the shock is drawn from a lognormal distribution with mean and standard deviation equal to 0 and 0.003 . Logged reported population is then $\ln (r) \cdot$ shock. 
Figure 5: Illustration of the procedure used to identify bunching

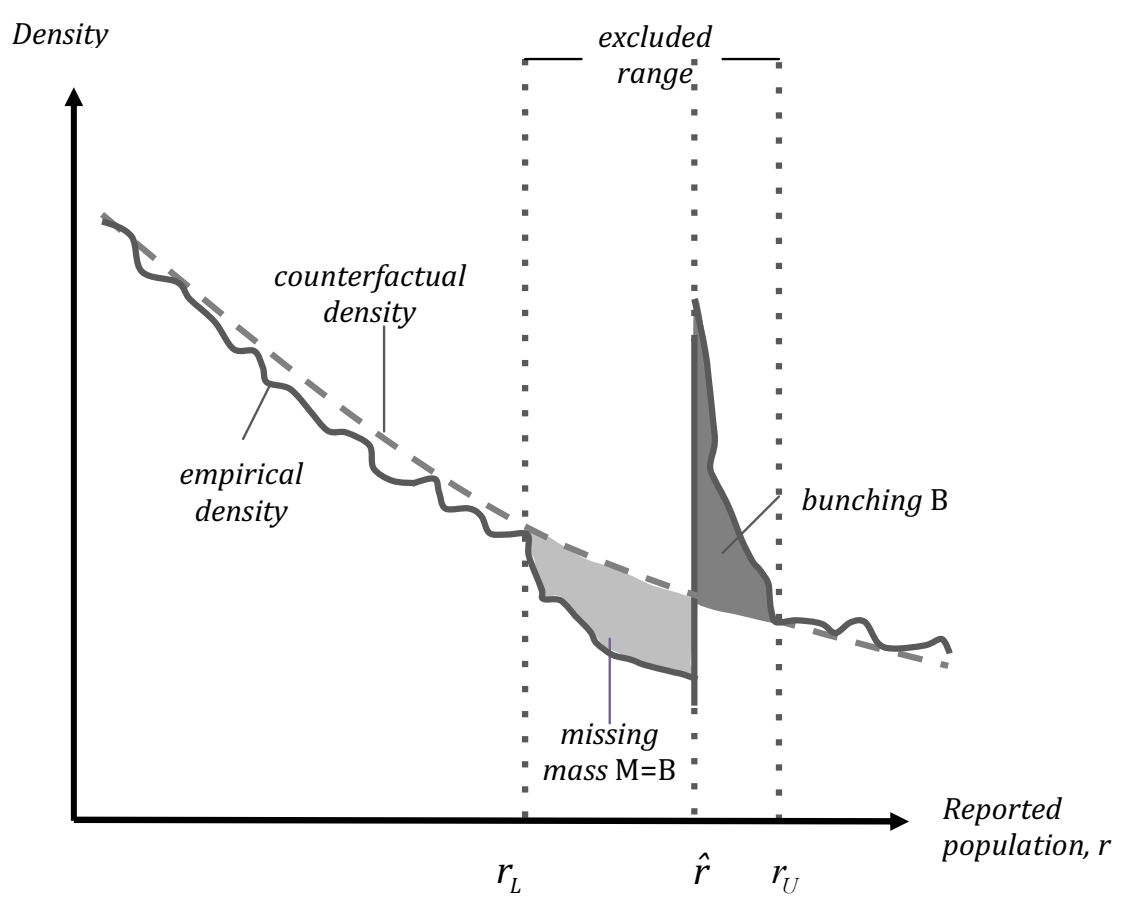


Figure 6: Baseline graph: 5,000-threshold

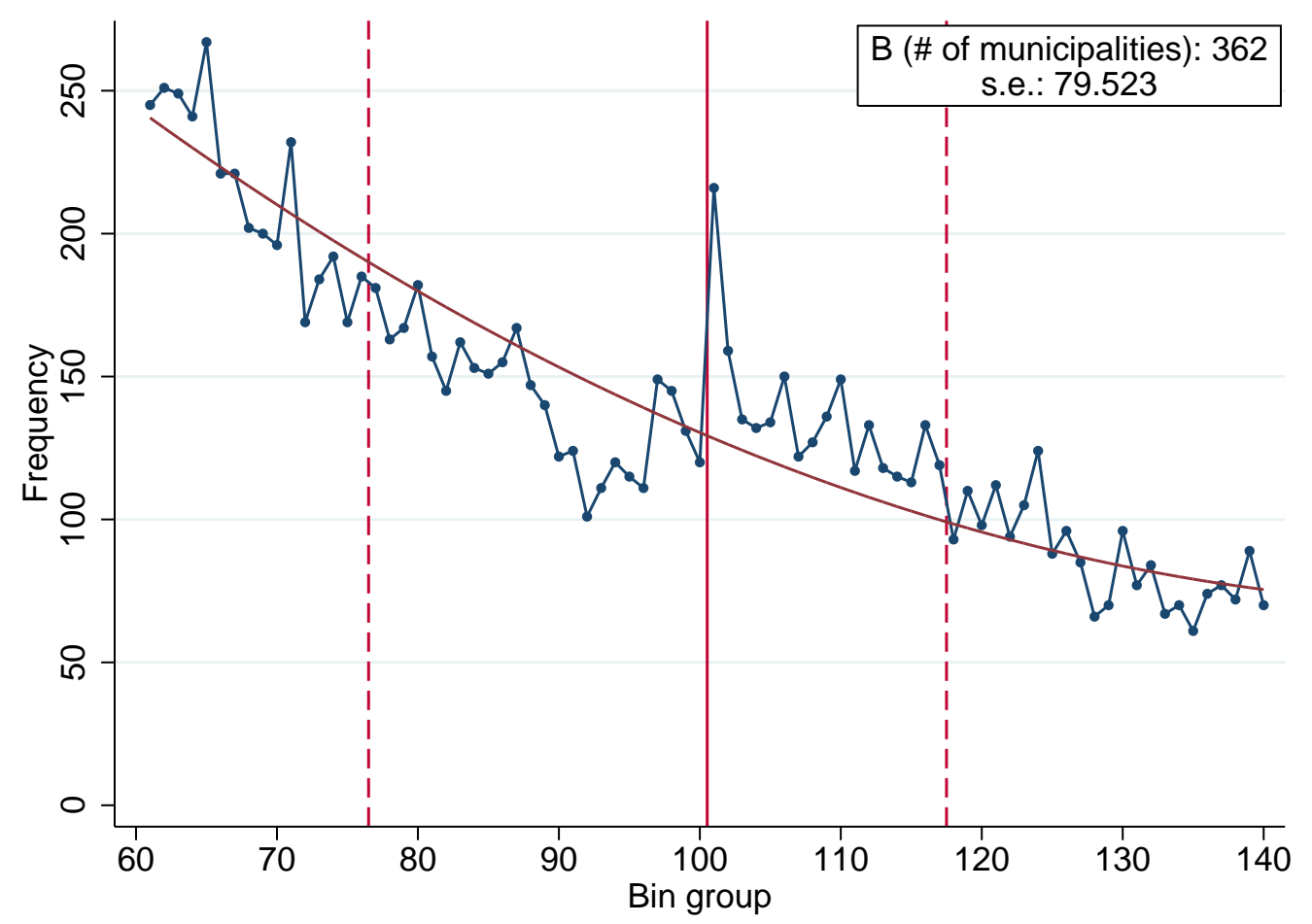

(a) notching

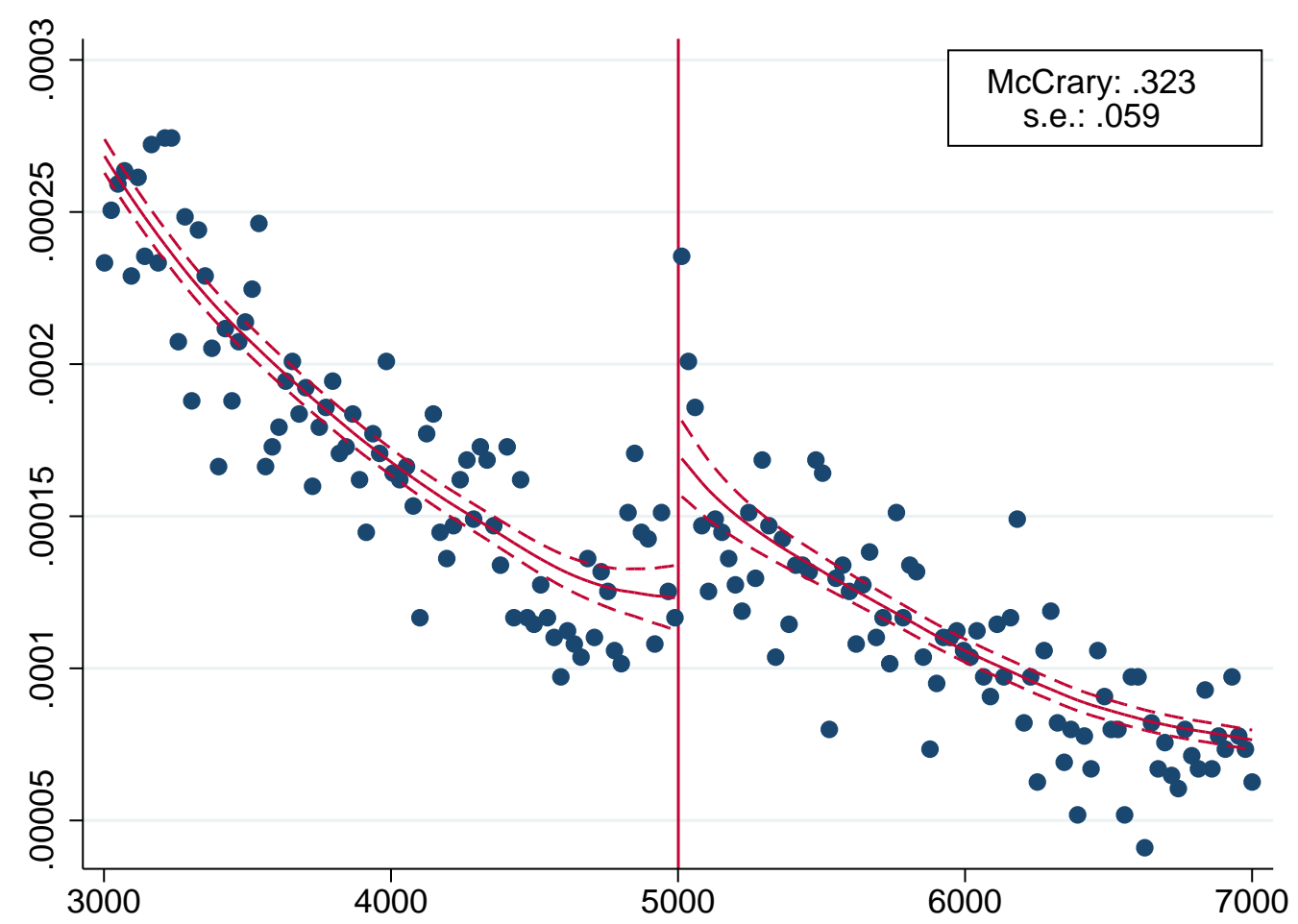

(b) McCrary

Notes: Notching around 5000 inhabitants. Bins of 50 inhabitant size in panel a). Parameters chosen automatically in panel b). Pooled for 1998-2011. On the vertical axis, bunching is expressed in frequencies and the McCrary (2008) test in densities. The range of the horizontal is identical in both graphs, but expressed in the bins included (bunching) and population (McCrary, 2008). 
Figure 7: Bunching with varying levels of enforcement: 5,000-threshold
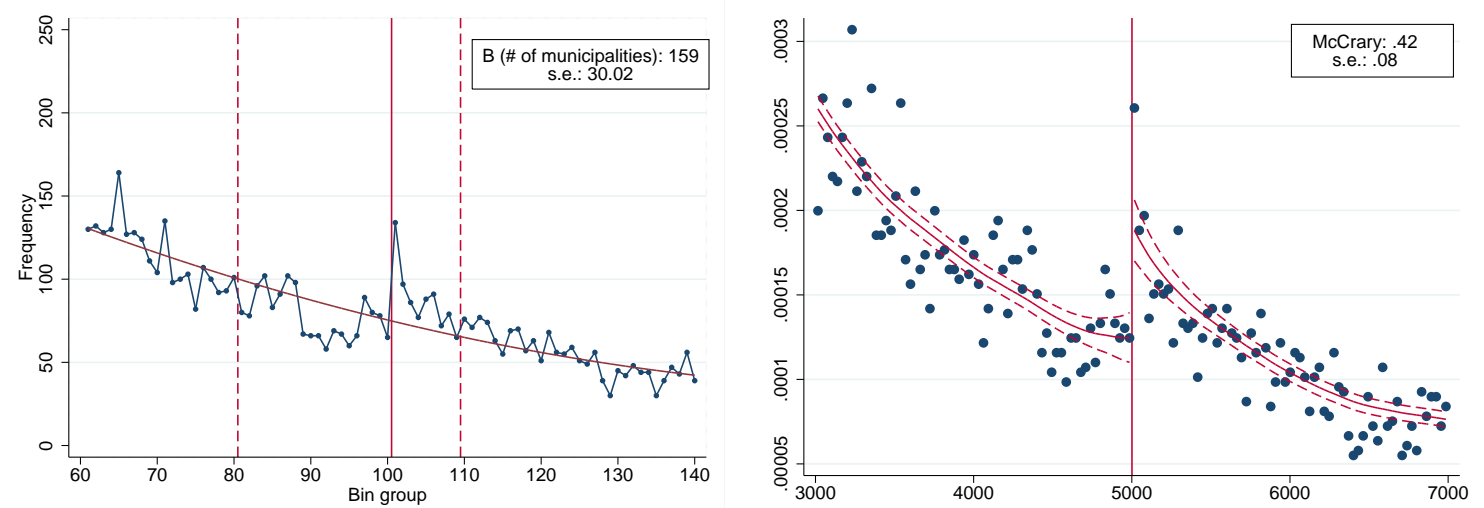

(a) 1998-2005 -bunching

(b) 1998-2005 - McCrary
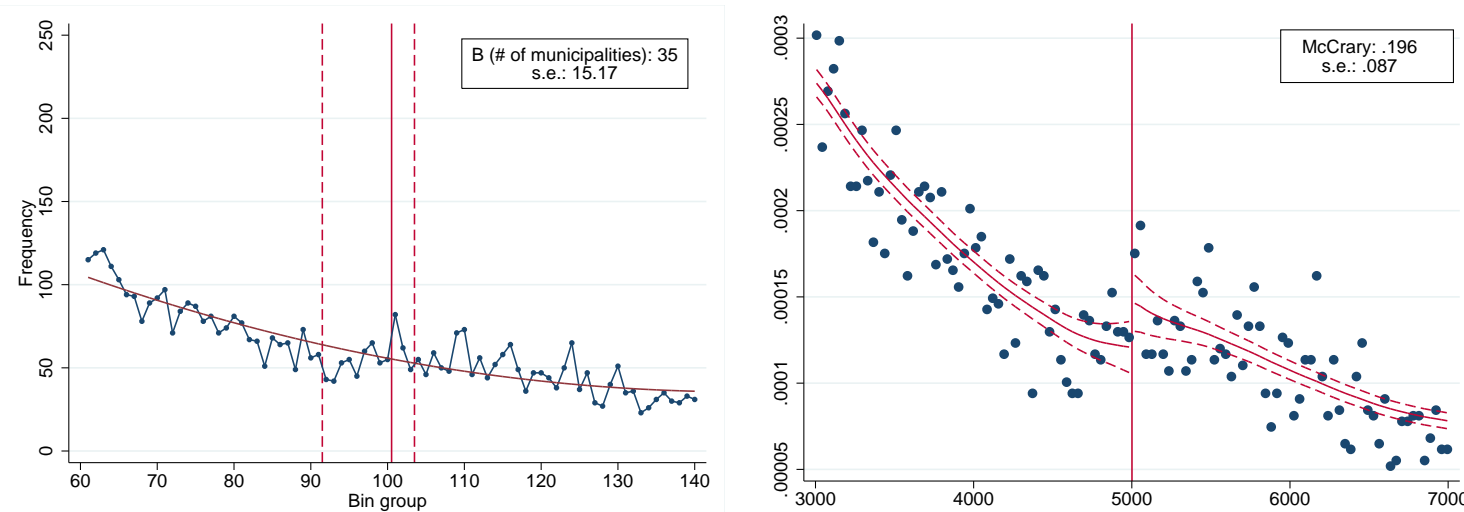

(c) 2006-2011 - bunching

(d) 2006-2011 - McCrary

Notes: notching around 5000 (panel a and b) inhabitants. The size of each bin is $1 \%$ of the threshold (i.e. 50 inhabitants). Pooled for 1998-2005 (panel a) and 2006-2011 (panel b). On the vertical axis, bunching is expressed in frequencies and the McCrary (2008) test in densities. The range of the horizontal is identical in both graphs, but expressed in the bins included (bunching) and population (McCrary, 2008). 
Figure 8: Bunching in the Census population figures

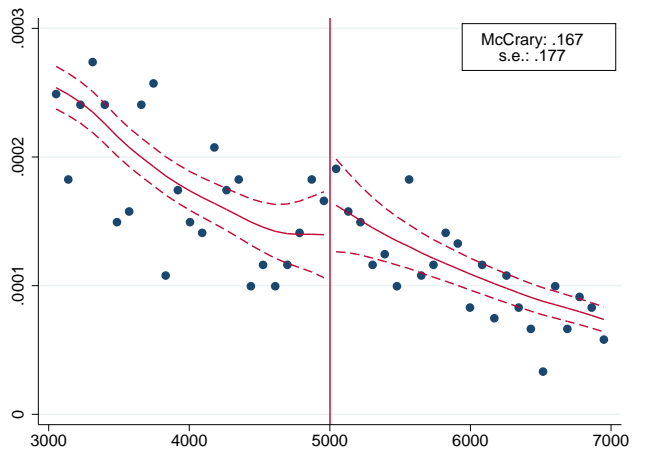

(a) 2001

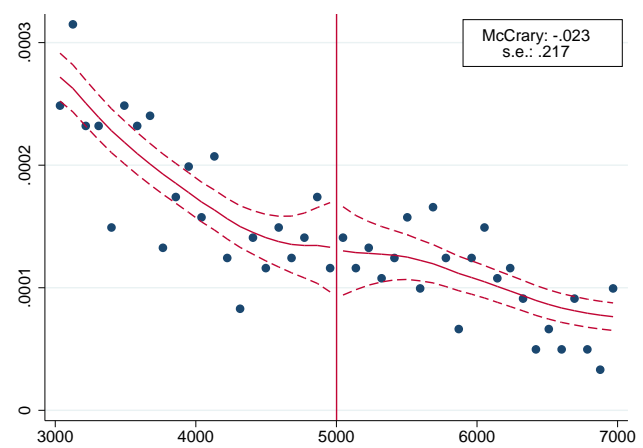

(b) 2011

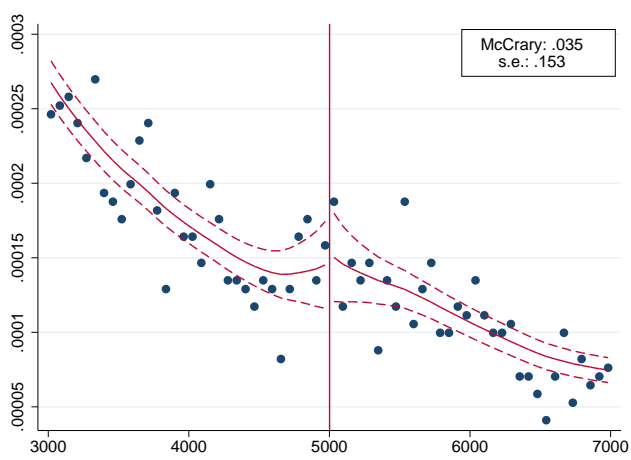

(c) 2001 and 2011 pooled

Notes: McCrary (2008) test on 2001, 2011, and pooled census information. Bandwidth and binwidth automatically determined by the routine.

Figure 9: Bunching at the 20,000 threshold

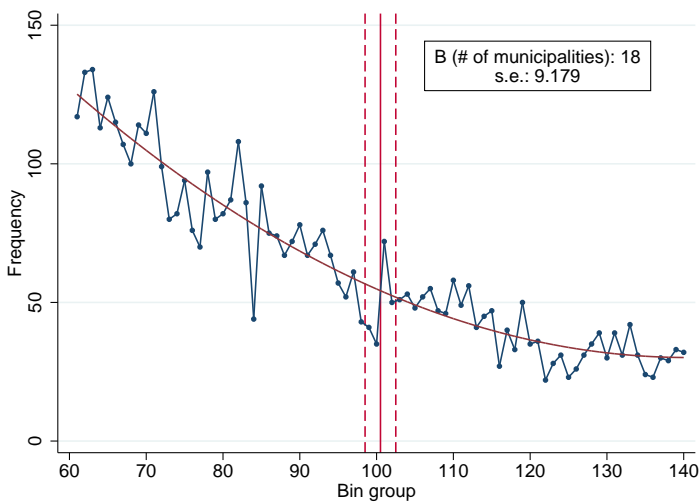

(a) 1998-2011 - 20,000 inhabitants

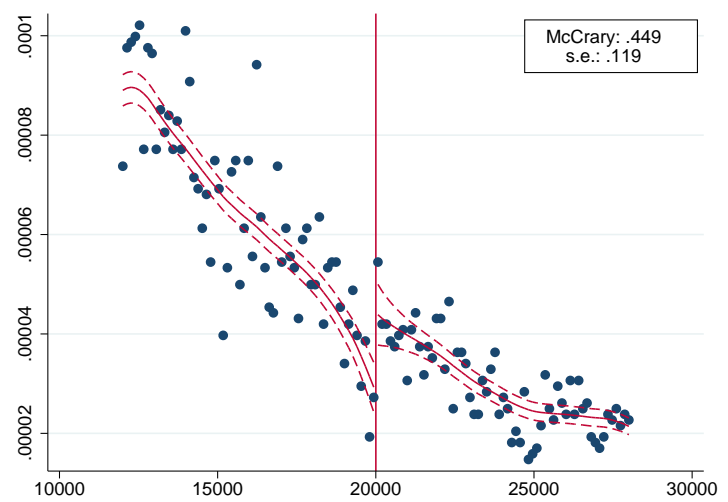

(b) 1998-2011 - 20,000 inhabitants

Notes: Notching around 20,000 inhabitants. The size of each bin is $1 \%$ of the threshold (i.e. 100 or 200 inhabitants, respectively). On the vertical axis, bunching is expressed in frequencies and the McCrary (2008) test in densities. The range of the horizontal is identical in both graphs, but expressed in the bins included (bunching) and population (McCrary, 2008). 
Figure 10: Other policies changes at the 5,000 threshold

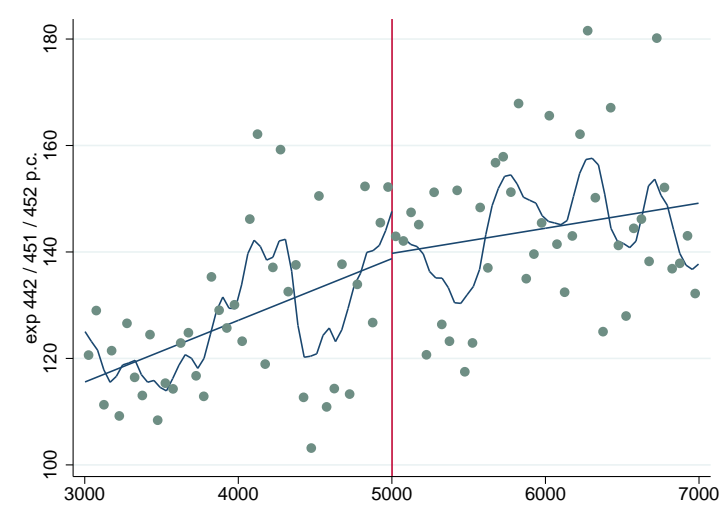

(a) expenditure responsibilities

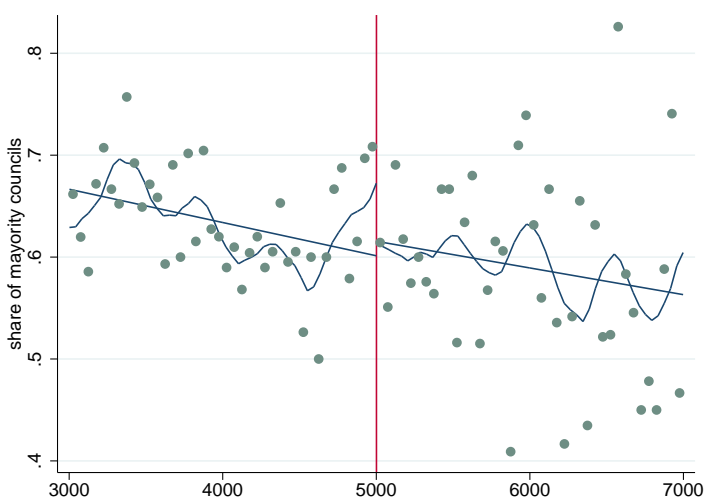

(b) council fragmentation

Notes: a) per-capita expenditures in items 442, 451, 452 of the clasificación funcional de gasto which contain the expenditures that become mandatory at the 5000 inhabitants threshold (public parcs, waste treatment, sports facilities, library); b) share of councils operating with majority. The figure is supplemented by local polynomials and a linear fit.

Figure 11: Bunching at the 10,000 threshold

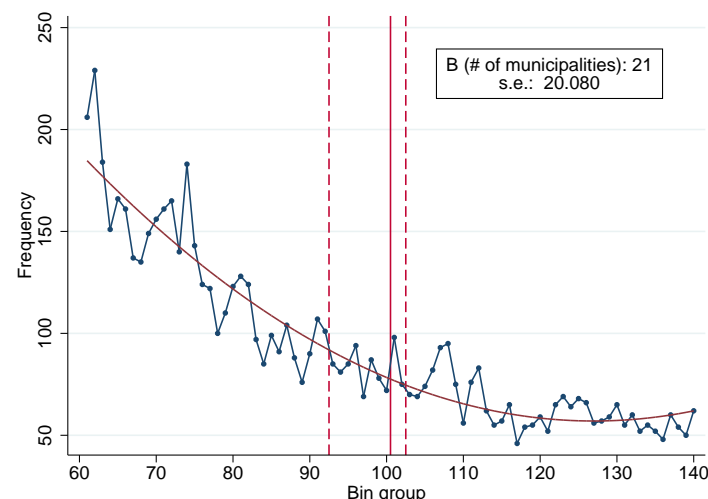

(a) $1998-2011$

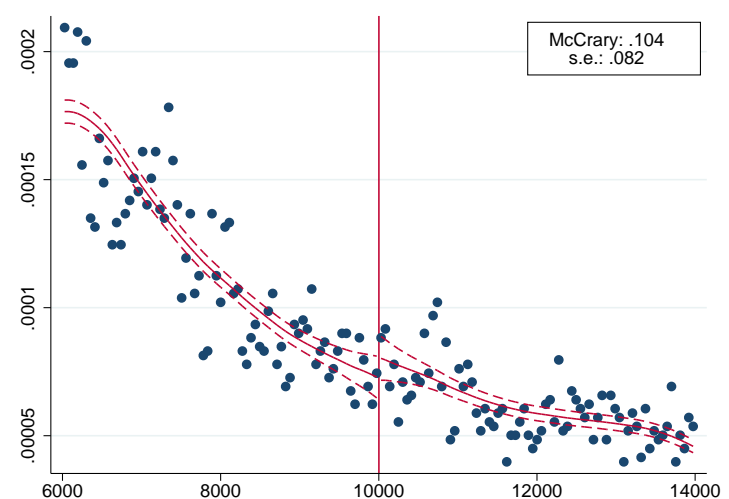

(b) $1998-2011$

Notes: notching around 10,000 inhabitants. The size of each bin is $1 \%$ of the threshold (i.e. 100 or 200 inhabitants, respectively). On the vertical axis, bunching is expressed in frequencies and the McCrary (2008) test in densities. The range of the horizontal is identical in both graphs, but expressed in the bins included (bunching) and population (McCrary). 
Table 1: \# of observations around thresholds (+/ - 40\%)

\begin{tabular}{lc}
\hline Threshold & \# yearly observations \\
\hline 5,000 & $785-811$ \\
10,000 & $503-566$ \\
20,000 & $326-375$ \\
50,000 & $105-145$ \\
\hline
\end{tabular}

Table 2: Baseline results - Bunching at the 5,000 threshold

\begin{tabular}{lccccc}
\hline Polynomial order $(\mathrm{q})$ & 2 & 2 & 2 & 3 & 4 \\
Bin size & 50 & 40 & 60 & 50 & 50 \\
\hline Range $\left[r_{L}, r_{U}\right]$ & {$[3850,5800]$} & {$[3840,5800]$} & {$[3860,5840]$} & {$[3550,5800]$} & {$[4400,5800]$} \\
$\#$ municipalities (B) & $362^{* * *}$ & $338^{* * *}$ & $366^{* * *}$ & $287^{* * *}$ & $191^{* *}$ \\
s.e. (B) & 79.523 & 72.908 & 76.236 & 77.581 & 91.275 \\
\% of respondents & 0.100 & 0.092 & 0.102 & 0.060 & 0.110 \\
Average $d r$ & 63.319 & 71.270 & 66.270 & 71.934 & 53.957 \\
$\epsilon_{r_{L}, \alpha}$ & 0.403 & 0.408 & 0.398 & 0.688 & 0.100 \\
$\epsilon_{r, \alpha}$ & 0.013 & 0.015 & 0.014 & 0.021 & 0.006 \\
\hline McCrary & & \multicolumn{5}{c}{$0.323^{* * *}$} \\
s.e. (McCrary) & & 0.059 & & \\
\hline
\end{tabular}

Notes: Pooled observations 1998-2011. The McCrary (2008) test is based on the sample until the next population threshold is reached and calculated with automatic bandwidth and bin size determination. The standard error for $B$ is obtained by (residual) bootstrapping. ${ }^{* * *} p<0.01,{ }^{* *} p<0.05,{ }^{*} p<0.1$. 
Table 3: The determinants of over-reporting

\begin{tabular}{|c|c|c|c|c|c|c|c|c|c|c|}
\hline & (1) & (2) & (3) & (4) & (5) & (6) & (7) & (8) & (9) & (10) \\
\hline \multicolumn{11}{|l|}{ Cheating Opportunities } \\
\hline foreigners & $\begin{array}{c}0.093^{* * *} \\
(0.031)\end{array}$ & & & & & & & & & $\begin{array}{c}0.153^{* * *} \\
(0.057)\end{array}$ \\
\hline second homes & & $0.009^{* *}$ & & & & & & & & 0.011 \\
\hline population turnover & & & $\begin{array}{l}-0.002 \\
(0.003)\end{array}$ & & & & & & & $\begin{array}{c}0.001 \\
(0.005)\end{array}$ \\
\hline \multicolumn{11}{|l|}{ Political Incentives } \\
\hline vote turnout & & & & $\begin{array}{c}-0.022^{* *} \\
(0.009)\end{array}$ & & & & & & $\begin{array}{l}-0.033^{*} \\
(0.018)\end{array}$ \\
\hline incumbent vote share & & & & & $\begin{array}{c}0.005 \\
(0.005)\end{array}$ & & & & & $\begin{array}{r}0.029^{* * *} \\
(0.011)\end{array}$ \\
\hline partisan alignment & & & & & & $\begin{array}{c}0.220 \\
(0.135)\end{array}$ & & & & $\begin{array}{l}0.357^{*} \\
(0.213)\end{array}$ \\
\hline $\begin{array}{l}\text { Fiscal Incentives } \\
\text { debt service }\end{array}$ & & & & & & & $\begin{array}{l}-0.090 \\
(0.953)\end{array}$ & & & $\begin{array}{c}0.478 \\
(1.288)\end{array}$ \\
\hline property tax rate & & & & & & & & $\begin{array}{c}0.325 \\
(0.421)\end{array}$ & & $\begin{array}{c}0.102 \\
(0.552)\end{array}$ \\
\hline business tax rate & & & & & & & & & $\begin{array}{l}-0.036 \\
(0.203)\end{array}$ & $\begin{array}{l}-0.319 \\
(0.336)\end{array}$ \\
\hline
\end{tabular}

Notes: Marginal effects of logit estimates. The binary dependent variable in all models is =1 if the January 2002 register figure is above the 5,000 threshold while the November 2001 figure is below (cheaters, 27 cases), otherwise $=0$. Total observation count: 160 . All regressions include as controls a constant, the distance to the 5,000 threshold and the population growth between 2000 and 2001. The estimates reported are marginal effects evaluated at a distance of 100 inhabitants to the threshold and at the mean for the rest of variables. Definition of variables: Foreigners: share of foreign inhabitants in total population in 2001; second homes: share of homes characterized as second residences in 2001; population turnover: Sum of in- and out-migration rates in the period 1991-2001. Vote turnout: turnout at the 2000 national elections at the municipal level: Incumbent vote share: Vote share of the mayor's party in the local council at the 1999 elections. Debt service is the sum of interest and principal debt payments as a share of total current revenue in 2000. Property tax rate is the 2000 statutory rate in the "Impuesto sobre la Propiedad Inmueble" while the business tax rate "Coeficiente de Incremento" is the 2000 tax rate in the "Impuesto sobre Actividades Económicas". Standard errors in parentheses. ${ }^{* * *} p<0.01,{ }^{* *}$ $p<0.05,{ }^{*} p<0.1$ 
Table 4: McCrary (2008)-test of census population

\begin{tabular}{lccc}
\hline & 2001 & 2011 & $2001 / 2011$ \\
\hline McCrary & 0.167 & -0.023 & 0.035 \\
s.e. (McCrary) & 0.177 & 0.217 & 0.153
\end{tabular}

Notes: McCrary (2008) test on 2001, 2011, and pooled census information. $40 \%$ window around the threshold.

Table 5: Bunching at the 20,000 and 10,000 threshold

\begin{tabular}{lccc}
\hline Threshold & a) 20,000 & & b) 10,000 \\
\cline { 2 - 2 } Range $\left[r_{L}, r_{U}\right]$ & {$[19800,20200]$} & & {$[9200,10200]$} \\
\# municipalities (B) & $18^{* *}$ & & 21 \\
s.e. (B) & 9.179 & & 20.080 \\
\% of respondents & 0.335 & & 0.031 \\
Average $d r$ & 72.357 & & 18.056 \\
$\epsilon_{r_{L}, \alpha}$ & 0.002 & &. \\
$\epsilon_{r, \alpha}$ & 0.0003 &. \\
\hline McCrary & $0.449^{* * *}$ & & 0.104 \\
s.e. (McCrary) & 0.119 & & 0.082 \\
\hline
\end{tabular}

Notes: Pooled observations 1998-2011. The McCrary (2008) test is based on the sample until the next population threshold will be reached and calculated with automatic bandwidth and bin size determination. No elasticities reported at 10,000 as grants remain unchanged. The standard error for $B$ is obtained by (residual) bootstrapping. ${ }^{* * *} p<0.01,{ }^{* *} p<0.05,{ }^{*} p<0.1$. 
2011/1, Oppedisano, V; Turati, G.: "What are the causes of educational inequalities and of their evolution over time in Europe? Evidence from PISA"

2011/2, Dahlberg, M; Edmark, K; Lundqvist, H.: "Ethnic diversity and preferences for redistribution"

2011/3, Canova, L.; Vaglio, A.: "Why do educated mothers matter? A model of parental help"

2011/4, Delgado, F.J.; Lago-Peñas, S.; Mayor, M.: "On the determinants of local tax rates: new evidence from Spain"

2011/5, Piolatto, A.; Schuett, F.: "A model of music piracy with popularity-dependent copying costs"

2011/6, Duch, N.; García-Estévez, J.; Parellada, M.: "Universities and regional economic growth in Spanish regions"

2011/7, Duch, N.; García-Estévez, J.: "Do universities affect firms' location decisions? Evidence from Spain"

2011/8, Dahlberg, M.; Mörk, E.: "Is there an election cycle in public employment? Separating time effects from election year effects"

2011/9, Costas-Pérez, E.; Solé-Ollé, A.; Sorribas-Navarro, P.: "Corruption scandals, press reporting, and accountability. Evidence from Spanish mayors"

2011/10, Choi, A.; Calero, J.; Escardíbul, J.O.: "Hell to touch the sky? Private tutoring and academic achievement in Korea"

2011/11, Mira Godinho, M.; Cartaxo, R.: "University patenting, licensing and technology transfer: how organizational context and available resources determine performance"

2011/12, Duch-Brown, N.; García-Quevedo, J.; Montolio, D.: "The link between public support and private R\&D effort: What is the optimal subsidy?"

2011/13, Breuillé, M.L.; Duran-Vigneron, P.; Samson, A.L.: "To assemble to resemble? A study of tax disparities among French municipalities"

2011/14, McCann, P.; Ortega-Argilés, R.: "Smart specialisation, regional growth and applications to EU cohesion policy"

2011/15, Montolio, D.; Trillas, F.: "Regulatory federalism and industrial policy in broadband telecommunications"

2011/16, Pelegrín, A.; Bolancé, C.: "Offshoring and company characteristics: some evidence from the analysis of Spanish firm data"

2011/17, Lin, C.: "Give me your wired and your highly skilled: measuring the impact of immigration policy on employers and shareholders"

2011/18, Bianchini, L.; Revelli, F.: "Green polities: urban environmental performance and government popularity"

2011/19, López Real, J.: "Family reunification or point-based immigration system? The case of the U.S. and Mexico"

2011/20, Bogliacino, F.; Piva, M.; Vivarelli, M.: "The impact of R\&D on employment in Europe: a firm-level analysis"

2011/21, Tonello, M.: "Mechanisms of peer interactions between native and non-native students: rejection or integration?"

2011/22, García-Quevedo, J.; Mas-Verdú, F.; Montolio, D.: "What type of innovative firms acquire knowledge intensive services and from which suppliers?"

2011/23, Banal-Estañol, A.; Macho-Stadler, I.; Pérez-Castrillo, D.: "Research output from university-industry collaborative projects"

2011/24, Ligthart, J.E.; Van Oudheusden, P.: "In government we trust: the role of fiscal decentralization"

2011/25, Mongrain, S.; Wilson, J.D.: "Tax competition with heterogeneous capital mobility"

2011/26, Caruso, R.; Costa, J.; Ricciuti, R.: "The probability of military rule in Africa, 1970-2007"

2011/27, Solé-Ollé, A.; Viladecans-Marsal, E.: "Local spending and the housing boom"

2011/28, Simón, H.; Ramos, R.; Sanromá, E.: "Occupational mobility of immigrants in a low skilled economy. The Spanish case"

2011/29, Piolatto, A.; Trotin, G.: "Optimal tax enforcement under prospect theory"

2011/30, Montolio, D; Piolatto, A.: "Financing public education when altruistic agents have retirement concerns"

2011/31, García-Quevedo, J.; Pellegrino, G.; Vivarelli, M.: "The determinants of YICs' R\&D activity"

2011/32, Goodspeed, T.J.: "Corruption, accountability, and decentralization: theory and evidence from Mexico"

2011/33, Pedraja, F.; Cordero, J.M.: "Analysis of alternative proposals to reform the Spanish intergovernmental transfer system for municipalities"

2011/34, Jofre-Monseny, J.; Sorribas-Navarro, P.; Vázquez-Grenno, J.: "Welfare spending and ethnic heterogeneity: evidence from a massive immigration wave"

2011/35, Lyytikäinen, T.: "Tax competition among local governments: evidence from a property tax reform in Finland"

2011/36, Brülhart, M.; Schmidheiny, K.: "Estimating the Rivalness of State-Level Inward FDI"

2011/37, García-Pérez, J.I.; Hidalgo-Hidalgo, M.; Robles-Zurita, J.A.: "Does grade retention affect achievement? Some evidence from Pisa"

2011/38, Boffa, f.; Panzar. J.: "Bottleneck co-ownership as a regulatory alternative" 
2011/39, González-Val, R.; Olmo, J.: "Growth in a cross-section of cities: location, increasing returns or random growth?"

2011/40, Anesi, V.; De Donder, P.: "Voting under the threat of secession: accommodation vs. repression"

2011/41, Di Pietro, G.; Mora, T.: "The effect of the l'Aquila earthquake on labour market outcomes"

2011/42, Brueckner, J.K.; Neumark, D.: "Beaches, sunshine, and public-sector pay: theory and evidence on amenities and rent extraction by government workers"

2011/43, Cortés, D.: "Decentralization of government and contracting with the private sector"

2011/44, Turati, G.; Montolio, D.; Piacenza, M.: "Fiscal decentralisation, private school funding, and students' achievements. A tale from two Roman catholic countries"

2012/1, Montolio, D.; Trujillo, E.: "What drives investment in telecommunications? The role of regulation, firms' internationalization and market knowledge"

2012/2, Giesen, K.; Suedekum, J.: "The size distribution across all "cities": a unifying approach"

2012/3, Foremny, D.; Riedel, N.: "Business taxes and the electoral cycle"

2012/4, García-Estévez, J.; Duch-Brown, N.: "Student graduation: to what extent does university expenditure matter?"

2012/5, Durán-Cabré, J.M.; Esteller-Moré, A.; Salvadori, L.: "Empirical evidence on horizontal competition in tax enforcement"

2012/6, Pickering, A.C.; Rockey, J.: "Ideology and the growth of US state government"

2012/7, Vergolini, L.; Zanini, N.: "How does aid matter? The effect of financial aid on university enrolment decisions"

2012/8, Backus, P.: "Gibrat's law and legacy for non-profit organisations: a non-parametric analysis"

2012/9, Jofre-Monseny, J.; Marín-López, R.; Viladecans-Marsal, E.: "What underlies localization and urbanization economies? Evidence from the location of new firms"

2012/10, Mantovani, A.; Vandekerckhove, J.: "The strategic interplay between bundling and merging in complementary markets"

2012/11, Garcia-López, M.A.: "Urban spatial structure, suburbanization and transportation in Barcelona"

2012/12, Revelli, F.: "Business taxation and economic performance in hierarchical government structures"

2012/13, Arqué-Castells, P.; Mohnen, P.: "Sunk costs, extensive R\&D subsidies and permanent inducement effects"

2012/14, Boffa, F.; Piolatto, A.; Ponzetto, G.: "Centralization and accountability: theory and evidence from the Clean Air Act"

2012/15, Cheshire, P.C.; Hilber, C.A.L.; Kaplanis, I.: "Land use regulation and productivity - land matters: evidence from a UK supermarket chain"

2012/16, Choi, A.; Calero, J.: "The contribution of the disabled to the attainment of the Europe 2020 strategy headline targets"

2012/17, Silva, J.I.; Vázquez-Grenno, J.: "The ins and outs of unemployment in a two-tier labor market"

2012/18, González-Val, R.; Lanaspa, L.; Sanz, F.: "New evidence on Gibrat's law for cities"

2012/19, Vázquez-Grenno, J.: "Job search methods in times of crisis: native and immigrant strategies in Spain"

2012/20, Lessmann, C.: "Regional inequality and decentralization - an empirical analysis"

2012/21, Nuevo-Chiquero, A.: "Trends in shotgun marriages: the pill, the will or the cost?"

2012/22, Piil Damm, A.: "Neighborhood quality and labor market outcomes: evidence from quasi-random neighborhood assignment of immigrants"

2012/23, Ploeckl, F.: "Space, settlements, towns: the influence of geography and market access on settlement distribution and urbanization"

2012/24, Algan, Y.; Hémet, C.; Laitin, D.: "Diversity and local public goods: a natural experiment with exogenous residential allocation"

2012/25, Martinez, D.; Sjögren, T.: "Vertical externalities with lump-sum taxes: how much difference does unemployment make?"

2012/26, Cubel, M.; Sanchez-Pages, S.: "The effect of within-group inequality in a conflict against a unitary threat" 2012/27, Andini, M.; De Blasio, G.; Duranton, G.; Strange, W.C.: "Marshallian labor market pooling: evidence from Italy"

2012/28, Solé-Ollé, A.; Viladecans-Marsal, E.: "Do political parties matter for local land use policies?"

2012/29, Buonanno, P.; Durante, R.; Prarolo, G.; Vanin, P.: "Poor institutions, rich mines: resource curse and the origins of the Sicilian mafia"

2012/30, Anghel, B.; Cabrales, A.; Carro, J.M.: "Evaluating a bilingual education program in Spain: the impact beyond foreign language learning"

2012/31, Curto-Grau, M.; Solé-Ollé, A.; Sorribas-Navarro, P.: "Partisan targeting of inter-governmental transfers $\&$ state interference in local elections: evidence from Spain" 
2012/32, Kappeler, A.; Solé-Ollé, A.; Stephan, A.; Välilä, T.: "Does fiscal decentralization foster regional investment in productive infrastructure?"

2012/33, Rizzo, L.; Zanardi, A.: "Single vs double ballot and party coalitions: the impact on fiscal policy. Evidence from Italy"

2012/34, Ramachandran, R.: "Language use in education and primary schooling attainment: evidence from a natural experiment in Ethiopia"

2012/35, Rothstein, J.: "Teacher quality policy when supply matters"

2012/36, Ahlfeldt, G.M.: "The hidden dimensions of urbanity"

2012/37, Mora, T.; Gil, J.; Sicras-Mainar, A.: "The influence of BMI, obesity and overweight on medical costs: a panel data approach"

2012/38, Pelegrín, A.; García-Quevedo, J.: "Which firms are involved in foreign vertical integration?"

2012/39, Agasisti, T.; Longobardi, S.: "Inequality in education: can Italian disadvantaged students close the gap? A focus on resilience in the Italian school system"

2013/1, Sánchez-Vidal, M.; González-Val, R.; Viladecans-Marsal, E.: "Sequential city growth in the US: does age matter?"

2013/2, Hortas Rico, M.: "Sprawl, blight and the role of urban containment policies. Evidence from US cities"

2013/3, Lampón, J.F.; Cabanelas-Lorenzo, P-; Lago-Peñas, S.: "Why firms relocate their production overseas? The answer lies inside: corporate, logistic and technological determinants"

2013/4, Montolio, D.; Planells, S.: "Does tourism boost criminal activity? Evidence from a top touristic country"

2013/5, Garcia-López, M.A.; Holl, A.; Viladecans-Marsal, E.: "Suburbanization and highways: when the Romans, the Bourbons and the first cars still shape Spanish cities"

2013/6, Bosch, N.; Espasa, M.; Montolio, D.: "Should large Spanish municipalities be financially compensated? Costs and benefits of being a capital/central municipality"

2013/7, Escardíbul, J.O.; Mora, T.: "Teacher gender and student performance in mathematics. Evidence from Catalonia"

2013/8, Arqué-Castells, P.; Viladecans-Marsal, E.: "Banking towards development: evidence from the Spanish banking expansion plan"

2013/9, Asensio, J.; Gómez-Lobo, A.; Matas, A.: "How effective are policies to reduce gasoline consumption? Evaluating a quasi-natural experiment in Spain"

2013/10, Jofre-Monseny, J.: "The effects of unemployment benefits on migration in lagging regions"

2013/11, Segarra, A.; García-Quevedo, J.; Teruel, M.: "Financial constraints and the failure of innovation projects"

2013/12, Jerrim, J.; Choi, A.: "The mathematics skills of school children: How does England compare to the high performing East Asian jurisdictions?"

2013/13, González-Val, R.; Tirado-Fabregat, D.A.; Viladecans-Marsal, E.: "Market potential and city growth: Spain 1860-1960"

2013/14, Lundqvist, H.: "Is it worth it? On the returns to holding political office"

2013/15, Ahlfeldt, G.M.; Maennig, W.: "Homevoters vs. leasevoters: a spatial analysis of airport effects"

2013/16, Lampón, J.F.; Lago-Peñas, S.: "Factors behind international relocation and changes in production geography in the European automobile components industry"

2013/17, Guío, J.M.; Choi, A.: "Evolution of the school failure risk during the 2000 decade in Spain: analysis of Pisa results with a two-level logistic mode"

2013/18, Dahlby, B.; Rodden, J.: "A political economy model of the vertical fiscal gap and vertical fiscal imbalances in a federation"

2013/19, Acacia, F.; Cubel, M.: "Strategic voting and happiness"

2013/20, Hellerstein, J.K.; Kutzbach, M.J.; Neumark, D.: "Do labor market networks have an important spatial dimension?"

2013/21, Pellegrino, G.; Savona, M.: "Is money all? Financing versus knowledge and demand constraints to innovation"

2013/22, Lin, J.: "Regional resilience"

2013/23, Costa-Campi, M.T.; Duch-Brown, N.; García-Quevedo, J.: "R\&D drivers and obstacles to innovation in the energy industry"

2013/24, Huisman, R.; Stradnic, V.; Westgaard, S.: "Renewable energy and electricity prices: indirect empirical evidence from hydro power"

2013/25, Dargaud, E.; Mantovani, A.; Reggiani, C.: "The fight against cartels: a transatlantic perspective"

2013/26, Lambertini, L.; Mantovani, A.: "Feedback equilibria in a dynamic renewable resource oligopoly: preemption, voracity and exhaustion" 
2013/27, Feld, L.P.; Kalb, A.; Moessinger, M.D.; Osterloh, S.: "Sovereign bond market reactions to fiscal rules and no-bailout clauses - the Swiss experience"

2013/28, Hilber, C.A.L.; Vermeulen, W.: "The impact of supply constraints on house prices in England"

2013/29, Revelli, F.: "Tax limits and local democracy"

2013/30, Wang, R.; Wang, W.: "Dress-up contest: a dark side of fiscal decentralization"

2013/31, Dargaud, E.; Mantovani, A.; Reggiani, C.: "The fight against cartels: a transatlantic perspective"

2013/32, Saarimaa, T.; Tukiainen, J.: "Local representation and strategic voting: evidence from electoral boundary reforms"

2013/33, Agasisti, T.; Murtinu, S.: "Are we wasting public money? No! The effects of grants on Italian university students' performances"

2013/34, Flacher, D.; Harari-Kermadec, H.; Moulin, L.: "Financing higher education: a contributory scheme" 2013/35, Carozzi, F.; Repetto, L.: "Sending the pork home: birth town bias in transfers to Italian municipalities" 2013/36, Coad, A.; Frankish, J.S.; Roberts, R.G.; Storey, D.J.: "New venture survival and growth: Does the fog lift?"

2013/37, Giulietti, M.; Grossi, L.; Waterson, M.: "Revenues from storage in a competitive electricity market: Empirical evidence from Great Britain"

2014/1, Montolio, D.; Planells-Struse, S.: "When police patrols matter. The effect of police proximity on citizens' crime risk perception"

2014/2, Garcia-López, M.A.; Solé-Ollé, A.; Viladecans-Marsal, E.: "Do land use policies follow road construction?"

2014/3, Piolatto, A.; Rablen, M.D.: "Prospect theory and tax evasion: a reconsideration of the Yitzhaki puzzle"

2014/4, Cuberes, D.; González-Val, R.: "The effect of the Spanish Reconquest on Iberian Cities"

2014/5, Durán-Cabré, J.M.; Esteller-Moré, E.: "Tax professionals' view of the Spanish tax system: efficiency, equity and tax planning"

2014/6, Cubel, M.; Sanchez-Pages, S.: "Difference-form group contests"

2014/7, Del Rey, E.; Racionero, M.: "Choosing the type of income-contingent loan: risk-sharing versus riskpooling"

2014/8, Torregrosa Hetland, S.: "A fiscal revolution? Progressivity in the Spanish tax system, 1960-1990"

2014/9, Piolatto, A.: "Itemised deductions: a device to reduce tax evasion"

2014/10, Costa, M.T.; García-Quevedo, J.; Segarra, A.: "Energy efficiency determinants: an empirical analysis of Spanish innovative firms"

2014/11, García-Quevedo, J.; Pellegrino, G.; Savona, M.: "Reviving demand-pull perspectives: the effect of demand uncertainty and stagnancy on R\&D strategy"

2014/12, Calero, J.; Escardíbul, J.O.: "Barriers to non-formal professional training in Spain in periods of economic growth and crisis. An analysis with special attention to the effect of the previous human capital of workers"

2014/13, Cubel, M.; Sanchez-Pages, S.: "Gender differences and stereotypes in the beauty"

2014/14, Piolatto, A.; Schuett, F.: "Media competition and electoral politics"

2014/15, Montolio, D.; Trillas, F.; Trujillo-Baute, E.: "Regulatory environment and firm performance in EU telecommunications services"

2014/16, Lopez-Rodriguez, J.; Martinez, D.: "Beyond the R\&D effects on innovation: the contribution of nonR\&D activities to TFP growth in the EU"

2014/17, González-Val, R.: "Cross-sectional growth in US cities from 1990 to 2000"

2014/18, Vona, F.; Nicolli, F.: "Energy market liberalization and renewable energy policies in OECD countries"

2014/19, Curto-Grau, M.: "Voters' responsiveness to public employment policies"

2014/20, Duro, J.A.; Teixidó-Figueras, J.; Padilla, E.: "The causal factors of international inequality in co2 emissions per capita: a regression-based inequality decomposition analysis"

2014/21, Fleten, S.E.; Huisman, R.; Kilic, M.; Pennings, E.; Westgaard, S.: "Electricity futures prices: time varying sensitivity to fundamentals"

2014/22, Afcha, S.; García-Quevedo, J,: "The impact of R\&D subsidies on R\&D employment composition"

2014/23, Mir-Artigues, P.; del Río, P.: "Combining tariffs, investment subsidies and soft loans in a renewable electricity deployment policy"

2014/24, Romero-Jordán, D.; del Río, P.; Peñasco, C.: "Household electricity demand in Spanish regions. Public policy implications"

2014/25, Salinas, P.: "The effect of decentralization on educational outcomes: real autonomy matters!"

2014/26, Solé-Ollé, A.; Sorribas-Navarro, P.: "Does corruption erode trust in government? Evidence from a recent surge of local scandals in Spain"

2014/27, Costas-Pérez, E.: "Political corruption and voter turnout: mobilization or disaffection?" 
2014/28, Cubel, M.; Nuevo-Chiquero, A.; Sanchez-Pages, S.; Vidal-Fernandez, M.: "Do personality traits affect productivity? Evidence from the LAB"

2014/29, Teresa Costa, M.T.; Trujillo-Baute, E.: "Retail price effects of feed-in tariff regulation"

2014/30, Kilic, M.; Trujillo-Baute, E.: "The stabilizing effect of hydro reservoir levels on intraday power prices under wind forecast errors"

2014/31, Costa-Campi, M.T.; Duch-Brown, N.: "The diffusion of patented oil and gas technology with environmental uses: a forward patent citation analysis"

2014/32, Ramos, R.; Sanromá, E.; Simón, H.: "Public-private sector wage differentials by type of contract: evidence from Spain"

2014/33, Backus, P.; Esteller-Moré, A.: "Is income redistribution a form of insurance, a public good or both?"

2014/34, Huisman, R.; Trujillo-Baute, E.: "Costs of power supply flexibility: the indirect impact of a Spanish policy change"

2014/35, Jerrim, J.; Choi, A.; Simancas Rodríguez, R.: "Two-sample two-stage least squares (TSTSLS) estimates of earnings mobility: how consistent are they?"

2014/36, Mantovani, A.; Tarola, O.; Vergari, C.: "Hedonic quality, social norms, and environmental campaigns"

2014/37, Ferraresi, M.; Galmarini, U.; Rizzo, L.: "Local infrastructures and externalities: Does the size matter?"

2014/38, Ferraresi, M.; Rizzo, L.; Zanardi, A.: "Policy outcomes of single and double-ballot elections"

2015/1, Foremny, D.; Freier, R.; Moessinger, M-D.; Yeter, M.: "Overlapping political budget cycles in the legislative and the executive"

2015/2, Colombo, L.; Galmarini, U.: "Optimality and distortionary lobbying: regulating tobacco consumption"

2015/3, Pellegrino, G.: "Barriers to innovation: Can firm age help lower them?"

2015/4, Hémet, C.: "Diversity and employment prospects: neighbors matter!"

2015/5, Cubel, M.; Sanchez-Pages, S.: "An axiomatization of difference-form contest success functions"

2015/6, Choi, A.; Jerrim, J.: "The use (and misuse) of Pisa in guiding policy reform: the case of Spain"

2015/7, Durán-Cabré, J.M.; Esteller-Moré, A.; Salvadori, L.: "Empirical evidence on tax cooperation between sub-central administrations"

2015/8, Batalla-Bejerano, J.; Trujillo-Baute, E.: "Analysing the sensitivity of electricity system operational costs to deviations in supply and demand"

2015/9, Salvadori, L.: "Does tax enforcement counteract the negative effects of terrorism? A case study of the Basque Country"

2015/10, Montolio, D.; Planells-Struse, S.: "How time shapes crime: the temporal impacts of football matches on crime"

2015/11, Piolatto, A.: "Online booking and information: competition and welfare consequences of review aggregators"

2015/12, Boffa, F.; Pingali, V.; Sala, F.: "Strategic investment in merchant transmission: the impact of capacity utilization rules"

2015/13, Slemrod, J.: "Tax administration and tax systems"

2015/14, Arqué-Castells, P.; Cartaxo, R.M.; García-Quevedo, J.; Mira Godinho, M.: "How inventor royalty shares affect patenting and income in Portugal and Spain"

2015/15, Montolio, D.; Planells-Struse, S.: "Measuring the negative externalities of a private leisure activity: hooligans and pickpockets around the stadium"

2015/16, Batalla-Bejerano, J.; Costa-Campi, M.T.; Trujillo-Baute, E.: "Unexpected consequences of liberalisation: metering, losses, load profiles and cost settlement in Spain's electricity system"

2015/17, Batalla-Bejerano, J.; Trujillo-Baute, E.: "Impacts of intermittent renewable generation on electricity system costs"

2015/18, Costa-Campi, M.T.; Paniagua, J.; Trujillo-Baute, E.: "Are energy market integrations a green light for FDI?"

2015/19, Jofre-Monseny, J.; Sánchez-Vidal, M.; Viladecans-Marsal, E.: "Big plant closures and agglomeration economies"

2015/20, Garcia-López, M.A.; Hémet, C.; Viladecans-Marsal, E.: "How does transportation shape intrametropolitan growth? An answer from the regional express rail"

2015/21, Esteller-Moré, A.; Galmarini, U.; Rizzo, L.: "Fiscal equalization under political pressures"

2015/22, Escardíbul, J.O.; Afcha, S.: "Determinants of doctorate holders' job satisfaction. An analysis by employment sector and type of satisfaction in Spain"

2015/23, Aidt, T.; Asatryan, Z.; Badalyan, L.; Heinemann, F.: "Vote buying or (political) business (cycles) as usual?"

2015/24, Albæk, K.: "A test of the 'lose it or use it' hypothesis in labour markets around the world"

2015/25, Angelucci, C.; Russo, A.: "Petty corruption and citizen feedback" 
2015/26, Moriconi, S.; Picard, P.M.; Zanaj, S.: "Commodity taxation and regulatory competition" 2015/27, Brekke, K.R.; Garcia Pires, A.J.; Schindler, D.; Schjelderup, G.: "Capital taxation and imperfect competition: ACE vs. CBIT"

2015/28, Redonda, A.: "Market structure, the functional form of demand and the sensitivity of the vertical reaction function"

2015/29, Ramos, R.; Sanromá, E.; Simón, H.: "An analysis of wage differentials between full-and part-time workers in Spain"

2015/30, Garcia-López, M.A.; Pasidis, I.; Viladecans-Marsal, E.: "Express delivery to the suburbs the effects of transportation in Europe's heterogeneous cities"

2015/31, Torregrosa, S.: "Bypassing progressive taxation: fraud and base erosion in the Spanish income tax (19702001)"

2015/32, Choi, H.; Choi, A.: "When one door closes: the impact of the hagwon curfew on the consumption of private tutoring in the republic of Korea"

2015/33, Escardíbul, J.O.; Helmy, N.: "Decentralisation and school autonomy impact on the quality of education: the case of two MENA countries"

2015/34, González-Val, R.; Marcén, M.: "Divorce and the business cycle: a cross-country analysis"

2015/35, Calero, J.; Choi, A.: "The distribution of skills among the European adult population and unemployment: a comparative approach"

2015/36, Mediavilla, M.; Zancajo, A.: "Is there real freedom of school choice? An analysis from Chile"

2015/37, Daniele, G.: "Strike one to educate one hundred: organized crime, political selection and politicians' ability"

2015/38, González-Val, R.; Marcén, M.: "Regional unemployment, marriage, and divorce" 
